\title{
The Imperative of Citizenship: Thoughts on Political Engagement in the Writings of Hannah Arendt
}

\author{
Jacob Ross Marthaller \\ Bachelor of Arts, California State University-Fullerton
}

A Thesis presented to the Graduate Faculty at the University of Virginia in Candidacy for the Degree of Master of Arts, Department of Religious Studies 


\begin{abstract}
In this thesis, I endorse Hannah Arendt's notion of political engagement, arguing that she provides crucial resources to ameliorate contemporary dysfunctions in American governance. However, while Arendt's writings constructively call for a citizenry to engage in politics, certain aspects of her work remain vague and indeterminate, and she is particularly inattentive to how distinct interlocutors configure an act of public deliberation. Following an introductory chapter explaining her relevance for modern civic life, I correct this aporia, beginning by probing her tenet of plurality through post-structuralist thought. In doing so, I affirm the notion of discursively formed social agents, simultaneously contending that an act of political engagement must acknowledge the multiplicity of identities informing it.

In chapter three, I put my exposition of Arendt in conversation with Jeffrey Stout and the recent work of Jürgen Habermas, using these thinkers to analyze the role of religion in public life. As the latter two authors are eager to establish, democratic politics are somehow lacking if individuals cannot draw from those beliefs and practices that play an integral role in shaping their lives, and I argue alongside them in asserting that religiously motivated rationale ought to have validity in the public sphere. Finally, I contend that religion can be valuable for political engagement, and I conclude by reexamining what Arendt's thought offers contemporary readers.
\end{abstract}




\section{Acknowledgements}

Many persons - far too many to name - are due thanks for helping me think through this thesis. If nothing else, this project attests to the fact that no piece of scholarship exists in a vacuum, and I see this thesis as confirmation of the exceptional caliber of scholars I have had the good fortune of studying with at the University of Virginia. In an effort to recognize those who offered me guidance, I begin by thanking my fellow graduate students, both in the Religious Studies department and beyond. Through our innumerable interactions, they have influenced me in ways I am still coming to comprehend, informing my writing in more ways than I presently know.

I should also take a moment to thank Liz Smith. Though her official title is "Graduate and Fiscal Coordinator," such a moniker vastly underplays how much Religious Studies graduate students rely on her. To be sure, graduate school is considerably easier when a near-omniscient lifeline like her is available to offer assistance, and I question whether I would have made it very far in the program without her insight and administrative expertise.

Special appreciation is due to the two professors who helped bring this project to fruition. Chuck Mathewes advised this thesis from start to finish; in fact, he suggested I read The Human Condition my third week in Charlottesville. I am indebted to his shrewd guidance, as his insightful questions and criticism habitually compelled me to proofread whatever I was bringing to his office just one more time. Jennifer Geddes also oversaw this project, providing critical insight and articulating inquiries that undoubtedly improved my writing. Without them, this thesis would not exist in its current form today, nor can its shortcomings be attributed to them.

My deepest gratitude is reserved for Jenna Marthaller, my wife. Not many people realize that when their spouse agrees to attend graduate school they in some sense consent to this endeavor as well. Even fewer people could have maintained the patience and poise she exhibited these past few years, as she taught me lessons not even Arendt could. For this reason-and so many more- this thesis is dedicated to her. 


\section{Foreword}

In December 2014, citizens of Charlottesville, Virginia gathered to protest a City Council meeting, hoping to enlighten officials in this small-town community about recent instances of racially motivated police violence. After seeing the current events surrounding the deaths and subsequent non-indictments in the cases of Michael Brown and Eric Garner, I myself attended the protest, aspiring to be a part of the process that would prevent similar phenomena from taking place in the future. I was far from alone, and walking into that council chamber it became clear to me what it meant to say a room was electric.

Indeed, the room was abuzz; with the NAACP, Albemarle County School officials, and scores of average Charlottesvillians in attendance and primed to voice their opinions, it was evident that my compatriots shared my sentiments. Drawing from the energy of the previous week's 25,000-person “Justice for All” march in Washington D.C., there was a palpable feeling that we as a community possessed the capacity to make change, a belief that Charlottesville could be a harbinger of progress. The clock crept toward seven, and as our congregation continued to swell in size, so did our confidence.

When the Council finally took their seats at the front of the room-visibly unsettled by the sheer quantity of attendees and no doubt concerned by the increasingly monumental task of holding a conventional meeting - a hush fell over the crowd. While intermittent bursts of "Hands Up, Don't Shoot!” occasionally rang out, everyone listened intently, as officials of the various organizations delivered statements requesting acknowledgement and action on the part of our representatives. Up first was Wes Bellamy, Albemarle High School teacher and political activist, 
who urged Council members to promptly comply with President Obama's recent injunction to install body cameras on police officers. Applause erupted the moment he finished.

Following Bellamy was Dr. Rick Turner, President of the Charlottesville-Albemarle Branch of the NAACP. He relayed what had taken place at the Washington march to the Council, and called on them to hear the plight of young black mothers across America, who feel as though their children face inevitable danger at the hands of police violence. To be sure, Dr. Turner's fervor and oratorical style was nothing short of moving, solidifying the resolve of those who had come to lend support. Many other citizens followed these two, echoing our common concern, voicing their anxieties and imploring the council to do something, anything, to rest our collective fears. The crowd concluded each speech with an ear-splitting ovation, springing up from their seats in unison each time as if the event itself was scripted.

As the assembly meandered on, however, it became apparent that the enthusiasm of the crowd was failing to reach the Council members themselves, who seemed more intent on securing order after each address and offering cookies to speakers — recompense for participating in the political process - than directly attending to their questions and concerns. They remained civil, of course, listening graciously to each presenter, taking notes as they went, and informing the public on the decisions and meetings that had supposedly already responded to these affairs. On one level, however, this was precisely the problem. While the citizens of Charlottesville were clearly in mourning - anxious not only for their own lives but for the lives of African-Americans across the country - and had come to their epicenter of power to converse with their governmental leaders, they were met primarily with blank faces and chocolate chips. Impassioned pleas for reform were reciprocated with monotone promises for budget allocation 
meetings and ultimately deflected. The disconnect between these two positions felt utterly tragic, and when the meeting dissolved due to unceasing interruptions by protesters, our resolve evaporated with it.

This was undoubtedly an impactful evening for me, one that lent a glimpse into the pervasiveness (and perversity) of governmental bureaucracy. Surely, I thought, the appeals of distressed mothers warranted more than two minutes and a promise to table the discussion for later. Unfortunately, the events of this evening proved the obverse, as the Council made it clear that one could effectively equate traffic congestion or limited parking downtown with the life and livelihood of African-Americans.

To be sure, the impasse represented by governmental bureaucracy (whether in Charlottesville, Richmond, or the District of Columbia) is an all too real phenomenon. Almost regardless of issue, the stymying effects of governmental ineptitude incessantly rears its heads against those who seek to engage in democratic discourse, necessitating the kind of critical response I have attempted here. Like religious studies scholar Jeffrey Stout's interactions with his environment, my political experiences in Charlottesville have "chang[ed] the character" of this text, providing me with a greater understanding of the importance of public deliberation. ${ }^{1}$ It is largely to understand the events I have witnessed that this thesis has been written, and it is my hope in thinking intently about them that I can, like the figure I spend much of my time discussing, make sense of what is going in my world. ${ }^{2}$

\footnotetext{
${ }^{1}$ Jeffrey Stout, Democracy and Tradition (Princeton, NJ: Princeton University, 2004), xiv.

${ }^{2}$ In an interview with journalist Günter Gaus, Arendt revealed that her primary reason for writing was her poor memory, as she wanted to be able to think about and comprehend the world in which she lived. In many ways, this mentality has impacted the way I perceive thinking and writing (especially in political theory), and I follow her example below. For a transcript of this interview, see "What Remains? The Language Remains': A Conversation with Günter Gaus" in The Portable Hannah Arendt, ed. Peter Baehr (New York: Penguin, 2000), 3-22.
} 


\section{Chapter One: Hannah Arendt, For Love of the World}

We live in dark times. One hardly needs to read current events to substantiate this claim, as even the most cursory grasp of human affairs reveals the tribulations that accompany everyday life. Violence abounds throughout the world, and income inequality perpetually constrains the livelihood of those who lack capital, leaving them with little to no recourse for modifying their socioeconomic circumstances. ${ }^{3}$

Further amplifying these issues, our contemporary political institutions appear wholly ineffectual, with our politicians serving more as objects of ridicule than reputable lawmakers. This topic has been covered at some length by legal reformist Philip K. Howard: in his most recent book, The Rule of Nobody, Howard asserts that expanding bureaucratic red tape has dissociated politicians from the political process, leaving them inept to accomplish even the most menial of tasks. ${ }^{4}$ And yet, this is not even the most urgent predicament we presently face. Although Howard believes the "mindless rigidity" and "ineptitude" of our politics ought to have generated indignation and outrage on a national scale, he recognizes that administrative hurdles and occluded legislative processes have also alienated the American citizenry from their government. ${ }^{5}$ As some have noted, this process has been in development for many years;

\footnotetext{
${ }^{3}$ For more on global poverty and the living conditions of the global poor, see http://www.worldbank.org/en/topic/ poverty. While Thomas Piketty's recent study of growing income inequality (Capital in the Twenty-First Century) has garnered considerable attention, I find Collins et. al.'s Economic Apartheid in America (New York: New Press, 2005) more pertinent to an American context.

${ }^{4}$ Philip K. Howard, The Rule of Nobody (New York: Norton, 2014), 1. Howard's book opens with the amusing yet frustrating anecdote of a New Jersey town's attempt to remove a fallen tree from a local river, which due to unthinking administrative oversight took a total of twelve days and thousands of dollars worth of permits. While Howard's initial casting of this narrative is somewhat humorous, he eventually shows the perils of a bureaucratically circumscribed government. For a less polemical view on problems in governance, see legal scholar Cass Sunstein's Wiser: Getting Beyond Groupthink to Make Groups Smarter, (Cambridge, MA: Harvard Business Review, 2015).

${ }^{5}$ The Rule of Nobody, 14.
} 
management theorist Peter Drucker sounds almost prophetic today when one reads his 1995 essay on the deficiencies of American governance, in which he writes that our political bodies stand to "bankrupt" themselves of efficacy or morality when they have "outgrown the structure, the policies, and the rules" they were intended for. ${ }^{6}$ Indeed, we appear to be living with this diagnosis today.

Regrettably, these predicaments might be more easily surmountable if fault were entirely with the slow-churning gears of bureaucracy. However, the motivations of our politicians are increasingly suspect, with Super PACs and duplicitous financial donations making corruption (or at least the specter of it) part of our common political experience. ${ }^{7}$ With little doubt that "rule by corporations" and other forms of governmental unscrupulousness have pervaded virtually all our most powerful organizations, it is clear our political environment is in desperate need of amelioration. ${ }^{8}$

Clearly, one of our most salient social dilemmas today stems from the incoherence of our political structures and the ideological divisiveness of the officials upholding them, which makes engaged debate arduous and consensus nearly impossible. While this poses a problem in and of itself, the marginalization of the American citizenry represents a more troublesome predicament altogether, as many Americans now feel warranted in believing they lack civic agency. ${ }^{9}$ As Howard's book polemically yet cogently argues, the inefficiency and surreptitiousness of

\footnotetext{
${ }^{6}$ Peter Drucker, "Really Reinventing Government," Atlantic Monthly (February 1995), available online at http://www. theatlantic.com/past/politics/polibig/reallyre.htm.

${ }^{7}$ For more on campaign finance in American government, see http://www.washingtonpost.com/blogs/the-fix /wp/2014/09/04/one-out-of-every-10-ads-run-in-the-2014-election-have-ties-to-the-koch-brothers/.

${ }^{8}$ Elisabeth Young-Bruehl, Why Arendt Matters (New Haven, CT: Yale, 2006), 75. For a sustained argument on the existence and effects of government corruption, see Lawrence Lessig, Republic, Lost: How Money Corrupts Congress - and a Plan to Stop It (New York: Hachette Book Group, 2011).

${ }^{9}$ A recent study has concluded that due to wealth inequality and other factors in crafting public policy, America may no longer actually be a democracy. See Martin Gilens and Benjamin I. Page, "Testing Theories of American Politics: Elites, Interest Groups, and Average Citizens," Perspectives on Politics 12, no. 3 (September 2014): 564-581.
} 
politicians leads to the wider society's disengagement from politics, a dilemma that is not distinctly American but nevertheless threatens us with the inability to make any kind of public choice.$^{10}$ It would appear, then, that a reinvigoration of our public discourse is long overdue.

While many approaches to negate our political apathy have been proposed, theorists, activists, and politicians alike have all foundered in their attempts to generate a vibrant and sustained political dialogue. Confronted by these problems, it seems a reanimation of civic engagement in America would require a complete conceptual transformation of the way citizens view their involvement with public life, an endeavor that necessitates critically revisiting previously harrowed ground. One thinker who lends assistance in examining this crucial question is the twentieth century political theorist Hannah Arendt (1906-1975), a provocative philosopher and an ardent proponent of a citizenry's obligation to engage in democratic politics.

For Arendt, societies put themselves in great danger by passively living alongside their governments; a social posture that on her view allowed the totalitarian states of Hitler and Stalin to come to fruition in the mid-twentieth century. ${ }^{11}$ For her, the purpose of political engagement is not merely to endorse or disapprove of particular pieces of legislation; rather, she conceives of politics—or more generally, public life—as possessing its own intrinsic value, offering citizens indispensable resources for interpreting their shared human condition, their collective "being-in-the-world." By failing to engage with their governments, Arendt thought citizens would lose their ability to make sense of or alter their lives, a predicament she identified in

\footnotetext{
${ }^{10}$ The Rule of Nobody, 14. For an exemplary study of how governmental corruption alienates citizens from the political process, see Colin Hay, Why We Hate Politics (Cambridge, UK: Polity, 2007.)

${ }^{11}$ The Rule of Nobody, 12.
} 
American politics near the end of her own life. ${ }^{12}$ It is to this "thoughtlessness" that my thesis is written, and through my engagement with Arendt I hope to find a way to mitigate our own political dysfunction.

In this introductory chapter I will draw from and analyze Hannah Arendt's notion of political engagement, delving especially into her conception of action and the space of appearance to illustrate how she thinks one can engage with the public sphere and vivify democratic political life. ${ }^{13}$ Despite the fact that I occasionally disagree with her, I use her model as a starting point for engrossing ourselves with our own political institutions and reviving our sense of political engagement, drawing on numerous aspects of our communities to do so.

Therefore, this initial exploration into Arendt's thought provides an overall foundation for this thesis, illuminating what aspects of her writings can be harnessed to revitalize our own public discourse. In turning to Arendt, it is necessary to see how her life shaped her work; while no scholar should be reduced to the experiences that befell them, her biography provides useful ancillary details for understanding her thought.

\section{Biography}

Born in 1906 into a secular German-Jewish household in Hanover, Germany, Hannah Arendt was one of the preeminent political theorists of the twentieth century, writing on a diverse range of topics from the nature of authority to the Civil Rights Movement. ${ }^{14}$ After growing up in

\footnotetext{
${ }^{12}$ Ibid., 13. For Arendt's perspective on the detrimental results of a government's loss of credibility, see her "Lying in Politics" in Crises of the Republic (New York: Mariner, 1973), 1-47. For Arendt's thought on the dangers posed by bureaucracy, see Hannah Arendt, The Human Condition (Chicago: University of Chicago, 1958), 38-49.

${ }^{13}$ While political apathy is anything but an exclusively American problem, my primary focus remains with the public affairs of the United States.

${ }^{14}$ Arendt scholar Margaret Canovan contends that Arendt's "German-ness and Jewish-ness" played a profound role in shaping her work. See, Margaret Canovan, The Political Thought of Hannah Arendt (London: Dent and Sons, 1974), vii.
} 
Königsberg and then Berlin, she attended the University of Marburg to study with philosopher Martin Heidegger, whose Being and Time would have a dramatic effect on her thought. ${ }^{15}$

Subsequent to her courses in Marburg, she studied at the University of Freiburg under Heidegger's mentor Edmund Husserl, followed by her pursuit of a doctorate with philosopher Karl Jaspers, finishing her dissertation on Augustine's conception of love in 1929.

With the rise of the Nazi Party, Arendt fled Germany in 1933, eventually arriving in Paris where she worked for a number of Jewish refugee organizations. It was during this exile that she began to cultivate her political principles, becoming socially active in both writing for Zionist publications and working for the Youth Aliyah (a group that transported Jewish children from Nazi Germany to Palestine). ${ }^{16}$ As could be expected, Arendt's period of "statelessness" left a lasting impression on her, serving as the motivating force and foundation to much of her political theory. In truth, it is difficult to exaggerate totalitarianism's influence on Arendt, and serious engagement with her work reveals that her thought is in many ways rooted in the knowledge of these "overwhelming political catastrophes." 17

Following her imprisonment in the Gurs internment camp in south-western France, Arendt emigrated to the United States in 1941, finally settling in New York to write and teach at several different universities (most notably The New School in New York City). In America she would complete The Human Condition, which contains her most rigorous examination of the modern interconnection between human life and politics. In The Human Condition, Arendt

\footnotetext{
${ }^{15}$ During this time, Heidegger and Arendt also had a brief love affair, which has been the topic of much recent scholarly interest. Despite its popularity, I do not treat the subject further in this thesis.

${ }^{16}$ Elisabeth Young-Bruehl, Hannah Arendt: For Love of the World (New Haven, CT: Yale, 1982), 107-121.

${ }^{17}$ Margaret Canovan, Hannah Arendt: A Reinterpretation of Her Political Thought (Cambridge, UK: Cambridge University, 1992), 7. In this book, Canovan admits her previous expository work failed to detail the immense influence totalitarianism had on Arendt. According to Canovan, Arendt's philosophy is shot through with her experiences of these events, and Canovan maintains that the Origins of Totalitarianism contains the key to Arendt's work.
} 
argues that engagement with the public sphere supplies the significance of human ${ }^{18}$ life, existing as the only place where people can truly "experience meaningfulness."19 In her own time, she thought political discourse was diminishing, thus necessitating her attempt to map out the historical intricacies of human existence and to recover a proper understanding of the political. Before delving directly into The Human Condition, it should be noted that while Arendt is often claimed by a variety of ideologues - from conservatives to liberal democrats to socialists - her own work is difficult to parse into a discrete school of thought. As a matter of fact, one of Arendt's greatest virtues is her aversion to any "totalizing ideology," another consequence of her encounter with totalitarianism. ${ }^{20}$ Above all, it must be remembered that Arendt's political theory prizes the notion of active citizenship, which allows a collected group of agents to "attain some measure of political efficacy," ultimately to democratically determine their own lives. ${ }^{21}$ Having established the basic moods and motivations of Arendt's thought, I now turn to a detailed exposition of The Human Condition, her seminal treatise on the nature of humankind, agency, and the necessity of political activity.

\section{The Vita Activa (Labor, Work, Action)}

Unlike many political theorists, Arendt's writings rarely offer syllogistic, linear arguments or concise prescriptions to particular issues. Rather, her philosophical style is marked

\footnotetext{
${ }^{18}$ Arendt's work is replete with gender-exclusive language like "man" and "mankind," and scholars have criticised her apparent disregard for feminist issues - especially Bonnie Honig in her Feminist Interpretations of Hannah Arendt (University Park, PA: Penn State University, 1995). To avoid this issue, I use gender-inclusive language in this thesis. ${ }^{19}$ Hannah Arendt, The Human Condition, 4.

${ }^{20}$ Jeffrey Isaac, Arendt, Camus, and Modern Rebellion (Ithaca, NY: Cornell University, 1998), 60. As Isaac persuasively argues, Arendt's antipathy for grandiose intellectual frameworks stems from her fear that they contributed to the creation of political organizations like Nazi Germany and the Soviet Union. In many ways, my interpretation of Arendt follows Isaac's, and this project is in large part an effort to elucidate a proper understanding of her work.

${ }^{21}$ Maurizio Passerin d'Entrèves, The Political Philosophy of Hannah Arendt (New York: Routledge, 1994), 2. It should also be noted that Passerin d'Entrèves correctly indicates the agonism of Arendt's political thought.
} 
by "striking conceptual distinctions" and "complex thematic strands," the interconnections of which are intended to provoke readers. ${ }^{22}$ The Human Condition is no exception: by introducing the vita activa - her term for the fundamental features of human life as a result of living in the world — and its constituent elements of labor, work, and action, Arendt elaborates not only on politics itself, but on the setting in which politics takes place. As Arendt scholar Margaret Canovan aptly notes, The Human Condition is Arendt's attempt to present a "prolegomena" to understanding democratic politics, a primer for comprehending human affairs. ${ }^{23}$

Therefore, in deciphering labor, work, and action, it is crucial to bear in mind that these categories are not to be read as a straightforward account of world or even Western history. On the contrary, Arendt sees them as archetypes that represent the various social stations humans have occupied throughout their existence, and it is by analyzing these activities through her phenomenological lens that she clarifies what is at stake in politics. ${ }^{24}$ Following a detailed chapter distinguishing the public from the private sphere, Arendt commences her exposition of the vita activa, beginning with the most foundational element of life: labor.

"Labor," Arendt writes, is the activity that "corresponds to the biological processes of the human body," the operations that are responsible for sustaining human life. ${ }^{25}$ Unlike work—-which creates durable and useful artifacts for society_labor's objective is not to bring a "finished product" into the world, but to contend with the necessities of preserving the physical body, to perpetually undergird human survival through the endlessly repetitive cycle of

\footnotetext{
${ }^{22}$ Dana Villa, "The development of Arendt's political thought" in The Cambridge Companion to Hannah Arendt, ed. Dana Villa (Cambridge, UK: Cambridge University, 2000), 1.

${ }^{23}$ Margaret Canovan, "Introduction," in Hannah Arendt, The Human Condition (Chicago: University of Chicago, 1958), ix.

${ }^{24}$ While labor and work are of subsidiary importance for Arendt, they remain integral to human life.

${ }^{25}$ The Human Condition, 81.
} 
production and consumption. ${ }^{26}$ In a critical engagement with Marx, Arendt contends that labor is essentially “man's metabolism with nature," allowing human beings to consume items derived from the natural world so they can satiate their desires and build a stable society. Although labor is clearly vital for supporting humanity, Arendt thought modern consumer culture was elevating it to a supreme position within the vita activa, leaving people with a conception of life that seldom sought anything beyond accumulating capital or "making a living." ${ }^{27}$ Of course, Arendt is not opposed to labor, only against its "undisputed predominance" in the hierarchy of human affairs, as well as mass society's assertion that human beings are chiefly laborers. ${ }^{28}$

At first glance, Arendt's diatribe against labor is puzzling, a polemic that is further convoluted by her extensive elucidation of Greek social life. However, further examination reveals that her trepidations stem from what she perceived as the modern age's receding distinction between the public and private sphere. Until the last several generations, Arendt argues, labor was associated exclusively with the household, the quintessential arena of the private realm. With modernity - and the influx of scientific innovations that came with it-labor's influence widened, immersing itself into the public sphere such that it was not only permissible but assumed that one would focus solely on production and consumption. ${ }^{29}$ Consequently the significance of labor was inflated while the distinct pieces of the vita activa became conflated, making "productivity and abundance" the operative principles of human life. ${ }^{30}$

\footnotetext{
${ }^{26}$ Ibid., 84.

${ }^{27}$ Ibid., 101.

${ }^{28}$ Ibid., 126.

${ }^{29}$ Passerin d'Entrèves, The Political Philosophy of Hannah Arendt, 5. Readers familiar with philosophical discourses on modernity may recognize Arendt's argument in writers like Weber, Horkheimer, and Adorno, all of whom informed her thought on this topic. See also, ibid., 25.

${ }^{30}$ The Cambridge Companion to Hannah Arendt, 4
} 
In addition, Arendt has reservations regarding labor because she thinks it contributes to the construction of what she called "the social." An obscure and seemingly paradoxical aspect of Arendt's work, political theorist Hanna Pitkin has explored the social in great detail, defining it as the "collectivity of people who-for whatever reason-conduct themselves in such a way that they cannot control or even intentionally influence the large-scale consequences of their activities." ${ }^{31}$ Arising especially with the retreating division between the public and private spheres - due particularly to the emergence of increasingly complex market economies, wherein "people are profoundly interdependent, yet no one is in charge"-Arendt thinks the the social "absorbs" autonomous individuals into a vast, unthinking collective, its near-irresistible power taking control over the life of a citizenry. ${ }^{32}$

For Arendt, the dilemma posed by the social is not entirely attributable to its impact on economics, but also in the way it empowers bureaucratic governmental structures, in which no one holds responsibility for her actions and citizens are ruled by "pure administration." 33 In this governmental "mass society" (what she would later call "rule by Nobody"34), Arendt thinks persons are effectively "devoured" by the "Blob," prohibiting them from participating in any kind of meaningful self-determination and leaving them with an altogether lifeless conception of politics. Constantly growing on her view, Arendt saw the social as regulating and subsequently "normalizing" human behavior, effacing individuality as well as one's ability to affect her

\footnotetext{
${ }^{31}$ Hanna Fenichel Pitkin, The Attack of the Blob: Hannah Arendt's Concept of the Social (Chicago: University of Chicago, 1998), 16.

${ }^{32}$ The Attack of the Blob, 11. Throughout this text, Pitkin refers to the science-fiction film The Blob, using the eponymous jelly like Blob's consumption of people to explain Arendt's account of the way one is inducted into mass society. It should also be noted that for Arendt, the rise of the social could not have occurred without the dissipation of totalitarianism, a point she made clear in The Origins of Totalitarianism (San Diego: Harvest Books, 1951). See especially chapter thirteen of this text, "Ideology and Terror."

${ }^{33}$ The Human Condition, 45.

${ }^{34}$ Crises of the Republic, 137.
} 
political environment. ${ }^{35}$ Although she errs in overlooking some of the recent accomplishments in social and economic life, Arendt's anxieties that labor and the social devalue authentic political engagement underpin her writings.

Indeed, once labor is vaulted over work and action and the distinction between the public and private sphere is blurred, Arendt thinks politics - that is, the indispensably human characteristic of "being together" 36 _ becomes subject to the social and necessity, wherein only instrumental concerns can be brought to the public realm. As individuals increasingly concern themselves with economics and policy over civic engagement and the intrinsic value of politics, Arendt asserts that something is lost in our concept of the political, that we in a sense forget how to participate in human affairs. To be truly political on Arendt's terms, citizens cannot be wholly concerned with public policy, but must instead be focused on surrounding themselves with a free and active citizenry, incessantly and ardently immersing themselves in the public sphere. ${ }^{37}$ Whereas labor is intended to be private and devoid of any kind of permanence, work constructs more substantial objects within the vita activa.

Just as labor contends with the processes of biological life in a cycle of production and consumption, work "fabricates" (poiesis) materials from the natural world, refashioning them into durable objects for advantageous human use. ${ }^{38}$ By "wrenching substances from their natural context and using them as material" for man-made things, work employs the craftsmen's strength

\footnotetext{
${ }^{35}$ The Attack of the Blob, 15.

${ }^{36}$ As will be made plain throughout this thesis, Arendt takes seriously the Aristotelian-Thomistic axiom that "man is by nature political, that is, social." See The Human Condition, 23.

${ }^{37}$ Craig Calhoun, "Plurality, Promises, and Public Spaces," in Hannah Arendt and the Meaning of Politics, eds. Craig Calhoun and John Mcgowan (Minneapolis: University of Minnesota, 1997), 234.

${ }^{38}$ The Human Condition, 136. While Arendt's distinction between work and labor is problematically vague, Bhikhu Parekh offers a helpful analogy in asserting that these entities are similar to Marx's concepts of abstract and concrete labor. See Bikhu Parekh, "Hannah Arendt's Critique of Marx" in Hannah Arendt: The Recovery of the Public World, ed. Melvyn A. Hill (New York: St. Martin's, 1979), 68.
} 
to construct artifacts, which then achieve a more substantial existence in the world than the results of labor..$^{39}$ Arendt's metaphor of cultivated land provides a valuable explanatory illustration on this point: while tilling soil is an obvious example of labor-it may in fact be her definitive example, for this kind of drudgery must be done perpetually and with strenuous effort—work done by a skilled artisan over a particular piece of property will eventually transform that area into cultivated land, thereby allowing that previously fallow ground to benefit humanity. ${ }^{40}$ In this way, Arendt concludes that work is an exercise in reification, in which manufactured artifacts become an enduring testament to a person or people's identity.

While Arendt writes that the activities associated with work (unlike labor) are capable of existing in and upbuilding the public sphere, she also claims that homo faber - the individual that occupies this position in society—only enters the public sphere to exchange the goods she fabricated in private, and that the essential activities of work are done in isolation.$^{41}$ Thus, work cannot correspond to politics on Arendt's view, nor can a utopian political space be manufactured by experts or technicians, a flaw she thinks the majority of Western political theory has committed. ${ }^{42}$ Even though work and labor are necessary ingredients of human life, neither of these principles can be considered "the measure of all things" for Arendt, nor do they approach the political sphere in the way action allows. ${ }^{43}$

\footnotetext{
${ }^{39}$ Margaret Canovan, The Political Thought of Hannah Arendt, 56. One could indicate a road or building as examples of these fabricated artifacts.

${ }^{40}$ The Human Condition, 138. This is not to say labor necessarily transforms into work over time, only that it can.

${ }^{41}$ Ibid., 161. To provide additional context, it should be noted that Arendt framed John Locke's conception of property and Adam Smith's understanding of value under her principle of work.

${ }^{42}$ On page 91 of The Art of the Impossible: Politics as Morality in Practice (New York: Knopf, 1994), the Czech dissident, politician, and theorist of totalitarianism Vaclav Havel (who knew Arendt's work well) seems to concur with Arendt's pre-Socratic notion of politics when he calls for society to "abandon the arrogant belief that the world is merely a puzzle to be solved, a machine with instructions for use waiting to be discovered."

${ }^{43}$ The Human Condition, 174.
} 
In distinction from these other two faculties, with action (praxis) Arendt introduces the most significant aspect of her vita activa, in so doing she explicates how her conception of politics contains more than economics or policy analysis. For Arendt, action is the only feature of the vita activa not constrained by necessity nor limited to upbuilding "the human artifice," the only archetypal element of human life that attests to the significance of the public realm. ${ }^{44}$ While labor and work are important units of the vita activa, they are merely "counterpoints" to action, which allows human beings to coexist together, to achieve some semblance of "everlastingness" by their speech and deeds. ${ }^{45}$ Although action remains a crucial element of her political framework, it is also notoriously misunderstood, with many critics misconstruing it as fodder for revolutionary violence in the vein of Marx or Lenin. ${ }^{46}$ Therefore, in this next section I make action more accessible by breaking it down into its constituent elements of plurality, natality, freedom. Through my analysis, I display how action facilitates human togetherness and brings Arendt's vision of the ideal polis into view, through which we can glean resources to correct our own political dysfunction.

The first significant component of action is plurality, which on Arendt's view corresponds to Aristotle's dictum that "men, not Man, live on the earth and inhabit the world."47 For Arendt, plurality demonstrates that human beings are unequivocally equal in one respect: they are infinitely distinct from one another. Whereas labor is fundamentally private and the essential activities of work can only be done in isolation, through plurality action acknowledges

\footnotetext{
${ }^{44}$ Calhoun, "Plurality, Promises, and Public Spaces," 237. While action does not necessarily entail public protest or revolution, it certainly contains an element of public speech and action, as my analysis will make clear.

45 The Human Condition, 13.

${ }^{46}$ As Canovan writes, with action Arendt is much less concerned with "building barricades and shooting down soldiers" and much more focused on citizens "stepping forward from their private lives into the light of public affairs." See Canovan, The Political Thought of Hannah Arendt, 58-60.

${ }^{47}$ Ibid., 7. Arendt writes that action is the "conditio per quam — of all political life."
} 
the equality and distinction of each individual in the public realm, who can subsequently congregate with one another and initiate political engagement. In this way, action can never be a solitary endeavor, as Arendt maintains that agents must rely on speaking and acting with those around them, coexisting with them in the public sphere to engage in something that could be called politics. $^{48}$

Speech is in fact a crucial element of plurality for Arendt, and communicative interaction becomes one of its operating principles. Through speech, Arendt thinks individuals "disclose their identity" to those around them, revealing their most intrinsic "motives and intentions" to their contemporaries and affirming the "who" they introduce to the public sphere. ${ }^{49}$ Rather than seeking to generate full agreement on a particular issue, Arendt views this "revelatory" character of speech as facilitating human plurality, providing resources to reinforce action. ${ }^{50}$ In this way, action situates plural interlocutors into innumerable "webs of relationships," producing a more stable structure for engaging with one another and "bestow[ing] significance upon the life of man as a unique individual." ${ }^{51}$ Still, Arendt must delineate how human plurality begins, a tenet she labels natality.

In Arendt's schema, natality makes plurality a possibility by birthing human beings into the world. On the one hand, Arendt's literal interpretation of natality stresses the fact that new people are constantly being brought into existence, signifying the potential nature of plurality. Even more crucial for her, however, is the consideration that natality parallels action's emphasis on making new beginnings in human affairs. Just as the physical birth of each human represents

\footnotetext{
${ }^{48}$ Ibid., 190. One drawback of action is its fragility, only existing while individuals are gathered together.

${ }^{49}$ Ibid., 179.

${ }^{50}$ Passerin d'Entrèves, The Political Philosophy of Hannah Arendt, 73.

${ }^{51}$ The Human Condition, 184.
} 
"something new and unique in this world," Arendt thinks each instance of action is itself an unprecedented and distinctive venture. ${ }^{52}$ Moreover, it is due to natality - to the fact that each citizen is herself an "initium" (beginning), rather than as Heidegger thought a being always on the road toward mortality - that one possesses the capability to act. ${ }^{53}$ Natality, then, contributes the spark to plurality, triggering the capacity to begin and inspiring hope for action's more beneficial outcomes, a point that prompted Arendt to claim that "miracles" were inherent to politics. ${ }^{54}$ Given that humanity comes into this world in these free and spontaneous ways, natality also provides a glimpse of human freedom, a way of understanding both how citizens can and why they ought to engage in action.

Put most simply, on Arendt's view freedom is one's ability to exercise political agency through action. However, it should be noted that Arendt's conception of freedom does not allude to negative liberty from the liberal tradition, nor does it necessarily connote freedom of the press or free speech. Rather, like natality, freedom entails "the capacity to begin," the ability to initiate new instances of action within the public sphere, a faculty "with which all human beings are endowed by virtue of being born." ${ }^{, 55}$ As one scholar observes, Arendt's notion of freedom resembles a Machiavellian act of virtù, in which persons exhibit excellence in their activities to a world made more accessible by Fortuna.$^{56}$ Thus, freedom is in some sense synonymous with one's competency to properly engage with the polis, and politics is the arena in which individuals freely "meet as equals" to accomplish their goals. ${ }^{57}$ While labor and work are

\footnotetext{
${ }^{52}$ Canovan, The Political Thought of Hannah Arendt, 59.

${ }^{53}$ Passerin d'Entrèves, The Political Thought of Hannah Arendt, 67.

${ }^{54}$ The Human Condition, 247.

${ }^{55}$ Passerin d'Entrèves, The Political Thought of Hannah Arendt, 66.

${ }^{56}$ James Miller, "The Pathos of Novelty: Hannah Arendt's Image of Freedom in the World" in Hannah Arendt: The Recovery of the Public World, 179.

${ }^{57}$ Margaret Canovan, The Political Thought of Hannah Arendt, 68.
} 
continuously constrained by necessity and utility, action liberates citizens from the obligations of private life, circumventing their indebtedness to repetitious social roles and allowing them to "actualize" their freedom in political engagement with one another. ${ }^{58}$ Therefore, for Arendt freedom is both the capacity to act and the goal to which that action is directed.

In this way, Arendt claims freedom is the "raison d'être of politics," which signifies to her that political groups should not be wholly transfixed on legislative agendas or special interests. Rather, she thinks they should be concerned with cultivating their engagement with the public sphere, manifesting their freedom and illuminating one another's ability to employ their own. Arendt's affinity for the American Revolution is illuminating on this point, explaining the proper demeanor one should maintain when engaging in civic life; whereas she thought the French Revolution was ultimately co-opted by "the desires of the masses," she regarded the American Revolution highly for what she perceived as the Founding Fathers' unrelenting desire to make freedom a "tangible, worldly reality," the determination to bring an engaged democracy into existence.$^{59}$ Thus, through freedom individual actors exhibit a sense of solidarity and in some ways create their polis. Having elaborated on these characteristics of action, it is important to note that Arendt is not introducing a utopian vision of politics. ${ }^{60}$ On the contrary, there are significant risks to action, and Arendt anticipates that the contingent nature of politics ought to compel one to exercise freedom with caution. It is to these mercurial features that I now turn, as I underscore action's volatility and necessity.

\footnotetext{
58 The Human Condition, 30-1.

${ }^{59}$ Canovan, The Political Thought of Hannah Arendt, 74-5.

${ }^{60}$ For Arendt, a utopian vision of politics ultimately founders in that it fails to account for the multitudinous human perspectives in public discourse. See The Human Condition, 227-8.
} 
Because action is a manifestation of freedom and plurality, Arendt claims that the conflicting "wills and intentions" of actors operating within the public sphere are unpredictable, and their political engagement can result in devastating outcomes. ${ }^{61}$ More specifically, because action takes place within the web of relationships, no one individual is responsible for its final, potentially "boundless" consequences. Rather, on Arendt's view human beings can only interact with these webs, contributing to political discourse but never wholly determining the aims and objectives of a given community, setting events in motion that may not be easily curbed. ${ }^{62}$

Further, for Arendt action is also irreversible, which is to say it initiates processes and reactions that may be incapable of being rescinded. ${ }^{63}$ Once a group engages with the relational webs, their action in some sense takes on a life of its own, refusing to be demolished like the products of work and possibly spreading across a social sphere. While these potential pitfalls might inspire us to abstain from politics altogether, Arendt offers an alternative, claiming that through forgiveness and making promises, individuals can overcome action's more deleterious consequences and lead a political life. Looking at these faculties in more detail, it is clear for her that through forgiveness individuals can exonerate transgressors for the detrimental effects of their action. ${ }^{64}$ Additionally, by making promises, citizens can prioritize preferred instances of action over others, providing a method for curtailing action's adverse effects even when they have gone askew. ${ }^{65}$ At the most basic level, Arendt's remedies against the inimical possibilities

\footnotetext{
${ }^{61}$ Ibid., 244.

${ }^{62}$ Passerin d'Entrèves, The Political Thought of Hannah Arendt, 81.

${ }^{63}$ The Human Condition, 233. In a footnote on this page Arendt quotes Nietzsche's Will to Power in the German: "You do not know the origin, we do not know the consequences...the value of action is unknown."

${ }^{64}$ Passerin d'Entrèves, The Political Thought of Hannah Arendt, 82.

${ }^{65}$ By this reasoning, one could rightly view treaties or other international agreements as promises in an Arendtian sense. See The Human Condition, 237.
} 
of action illustrate that further instances of action can rein previous ones in, thus solidifying the importance of perpetual political engagement within the vita activa.

As can be seen, Arendt's tenets of plurality, natality, and freedom coalesce to form a cohesive conception of action, wherein the sharing of words and deeds in the public sphere allows a group to actualize their agency, engage with their political environment, and create what could conceivably be called a polis. Clearly, Arendt is calling for a rejuvenation of the political realm, and her writings contend that action can create a durable public sphere. In looking to the kind of domain action generates, Arendt's vision of politics becomes more intelligible, as her ideal political space comes more closely into view.

\section{The Space of Appearance}

When action achieves its highest form, Arendt thinks a group of actors establishes what she calls "the space of appearance," that political location where "I appear to others as others appear before me." ${ }^{66}$ While the space of appearance can refer to a physical area, it is also an ethos, one counteracting the transience of human life by creating something that can be remembered throughout time. In this environment, individuals disclose their identity to their peers, using their freedom as a kind of virtuosity to reveal who they are most fully, in the process granting themselves an arena for further action. ${ }^{67}$

Given that it is a creation of action, Arendt clearly states that the space of appearance is highly fragile and ephemeral, with most people failing to occupy it during their lifetime. ${ }^{68}$ However, this space is a necessary ingredient of political life for her; not only does she regard it

\footnotetext{
${ }^{66}$ The Human Condition, 198.

${ }^{67}$ Margaret Canovan, Reinterpretation, 201.

${ }^{68}$ The Human Condition, 199.
} 
as the highest point of human reality, but it also provides some stability to human existence, mediating between the mindless rigidity of work and labor and the dangers inherent in action to prevent the social from spreading. ${ }^{69}$ Thus, the space of appearance must be perpetually recreated, not only because of its fleeting nature, but because it orients a community of actors as they engage with their polis, conferring on them the ability to live in a spirited public sphere. ${ }^{70}$

Once the space of appearance is created, Arendt contends that a group of actors obtain political power, a principle that on her view relies on the "promises, covenants, and mutual pledges" of a multitude of publicly engaged individuals. ${ }^{71}$ For Arendt, power is "the energy" that results from citizens acting together publicly, substantiating their political presence as they recognize and draw on the distinct identities of those around them to form a "common will.""72 Put another way, power occurs when individuals appear to one another and "act in concert," speaking to and persuading each other in the public sphere. ${ }^{73}$ Existing only potentially while a plurality of persons deliberate in public, power concretizes the civic agency an organization possesses, legitimizing the claims they make in political engagement and allowing them to become their most human selves. ${ }^{74}$

Accordingly, for Arendt the foundation of political communities does not lie with economic or policy claims, but in the space of appearance, the political expanse whose intrinsic value can only be measured by the criterion of greatness. This is something Arendt thought the

\footnotetext{
${ }^{69}$ Margaret Canovan, Reinterpretation, 148. As Pitkin notes, Arendt thought action could be brought "to bear on whatever is wrong in our present shared arrangements." See The Attack of The Blob, 2.

${ }^{70}$ Passerin d'Entrèves, The Political Thought of Hannah Arendt, 77.

${ }^{71}$ Leah Bradshaw, Acting and Thinking: The Political Thought of Hannah Arendt (Toronto: University of Toronto, 1989), 121.

72 Margaret Canovan, The Political Thought of Hannah Arendt, 71.

${ }^{73}$ The Human Condition, 200.

${ }^{74}$ Passerin d'Entrèves, The Political Thought of Hannah Arendt, 79. In The Human Condition Arendt claims that the space "actualizes" a person's being, articulating one's innate humanity. See The Human Condition, 208.
} 
ancient Athenians had discovered, and she considered their agonal political mode a kind of "ideal type" for her conception of the space of appearance and politics more generally. ${ }^{75}$

Something similar could be said of the American Founding Fathers, whose unwavering focus on the attainment of liberty is lauded by Arendt throughout her corpus. ${ }^{76}$ Though she admired innumerable political bodies throughout history, what unifies Arendt's exemplars of action is that they all stepped forward into the light of public affairs, a lesson we desperately need to bear in mind for our own political context.

To be sure, Arendt's space of appearance offers an inspiring vision of how to actualize potent human agency in the chaotic setting of human life. If present-day Americans were to begin acting in this way - that is, if they were to attempt to inaugurate the space of appearance through the method she outlines - they would undoubtedly generate vast amounts of power, which could then potentially be directed toward repairing our deficient governmental systems. I think an activity of this kind (on both the local and national level) is necessary today, and that we must look to engender this form of power by acting with one another in the public sphere. In the remainder of this thesis I will promote Arendt's thought as a way to invigorate this sense of public life in America, ultimately utilizing her as a remedy to combat our current political ailments. With that, I look to what we can glean from Arendt.

\section{What Arendt Offers}

Since her death in 1975, Arendt's work has seen a resurgence in popularity, as she has been the subject of numerous books, journals, conferences, and even one dramatic feature film.

\footnotetext{
${ }^{75}$ The Cambridge Companion to Hannah Arendt, 9. She was especially fond of Pericles' Funeral Oration, which she thought was a paramount example of inaugurating the space of appearance.

${ }^{76}$ Elisabeth Young-Bruehl, Why Arendt Matters, 196.
} 
Through her tripartite vita activa and her elaboration on how action inaugurates the space of appearance, she provides an ideal model for how individuals can enact their political agency in the public sphere, interacting with distinct and equal interlocutors to generate power. Not only does her vision underscore the inherent value of politics, but also it demonstrates how an engaged citizenry can revitalize their public life through civic engagement, thereby providing a model to rectify our current political paralysis. Though it would be wrong to presume her thought is providing a blueprint, she clearly imparts resources that are relevant for contemporary politics.

Of course, this is not to say Arendt is without her flaws, or that her thought could be easily implemented to propel political engagement. In spite of the fact that her work has been of incredible value across the academy, her inaccessible delivery—which one scholar called "symphonic rather than sequential"-leaves a great number of readers "bewildered."77 Furthermore, Arendt's analysis of the vita activa paints in such broad strokes that she often fails to attend to concrete issues in political engagement, including potential stumbling blocks in our own discourse. Thus, my assessment of Arendt's work necessitates covering these concepts in greater detail, filling in the aporias of her work to develop a more well-rounded conception of political engagement. I highlight two such complications now.

Chief among these difficulties is Arendt's consistent failure to contextualize her major operative terms, the foremost example being plurality. Although it is clear she believes a plurality of individuals makes political action possible, its exact nature is left largely undetermined. As such, imperative questions for understanding Arendt's work are who precisely

\footnotetext{
${ }^{77}$ Canovan, Reinterpretation, 3.
} 
these political actors are, how political engagement shapes them, and how their interaction subsequently configures that act of engagement. Similarly, Arendt is inattentive to how citizens can participate in civic discourse when a vital aspect of their identity is seen as inappropriate in the public sphere. While she thinks disclosing one's identity is a key component of action, she does not discuss how this disclosure is affected if persons are dismissed from dialogue based on principles they hold dear. The clearest case of this within our context involves the difficulties interlocutors face in grounding their political arguments in religious terms, as faith-based claims are often deemed unsuitable in the professedly neutral secular state. As I will claim in this thesis, diverse ideological viewpoints are not only valid but necessary within an act of political engagement, and individuals must be capable of drawing from the various aspects of their identity that can constructively contribute to public affairs.

In addition to these anxieties, some concerns have also been raised about the scope of Arendt's thought. Notably, philosopher Jürgen Habermas — whose work I analyze in more detail in chapter three-levelled an illuminating critique of this kind almost forty years ago. For Habermas, Arendt's communicative model of action overestimates the role praxis plays in actual political organizations, paying too little attention to "the strategic, the systematic, and the structural dimensions of politics." 78 While I find it contestable that Arendt "screens" all strategic and social considerations from her political writings, Habermas is correct to indicate that she does not adequately attend to the institutional complexities of government. ${ }^{79}$ As such, one of the ancillary goals of this thesis is to better elaborate on how an Arendtian view of political

\footnotetext{
${ }^{78}$ Passerin d'Entrèves, The Political Thought of Hannah Arendt, 99.

79 Jürgen Habermas, “Hannah Arendt's Communications Concept of Power,” Social Research 43, no. 4 (1977), 4.
} 
engagement can more fully manifest itself within our current political structures, a necessary task in our efforts to reinvigorate public discourse.

Undoubtedly, there are both virtues and shortcomings to Arendt's thought, and while many more issues within her work could be pressed, these questions require answers. Therefore, in this thesis I will attempt to unravel some of these uncertainties, expanding on and occasionally criticizing Arendt's political theory to generate a greater understanding of how to galvanize our interaction with the public sphere. By elaborating on the particulars of Arendt's writings and promoting what she called the "the priority of the political" as an ideal form of public deliberation, I hope to sketch a way to inspire and improve our political culture. ${ }^{80}$

\section{Outline for Remainder of Thesis}

In this thesis, I endorse Hannah Arendt's conception of political engagement, concurring with her in claiming that action is a necessary element of a vibrant and engaged polis. However, I also argue her phenomenological style and wide purview fails to elaborate on a number of key points, and my analysis attempts to obtain a clearer picture of what action and the space of appearance calls for. Thus, I begin in chapter two by affirming the notion of discursively formed social agents, drawing from Michel Foucault, Judith Butler, and Saba Mahmood to elaborate on the nature of distinct agents within human plurality. Through this chapter, I detail the underlying effects of citizens disclosing their identities to one another, as well as how this initiates an ideal political space and founds power for the politically engaged. Further, I maintain that by being situated into the pre-political webs of relationships, citizens bolster their association with one another and eventually procure agency for their involvement with the polis. Finally, I hold that

\footnotetext{
${ }^{80}$ Dana Villa, Public Freedom (Princeton, NJ: Princeton University, 2008), 96.
} 
an act of political engagement must acknowledge the multiplicity of identities constituting it, that plurality requires recognizing all of an interlocutor's personhood when they immerse themselves in civic life. In this way, I make an Arendtian argument for pluralism.

Following this discussion, I then contend in chapter three that diverse forms of argumentation do not detract from but in fact offer a more robust form of political engagement. To do this, I use Jeffrey Stout and the recent work of Jürgen Habermas to assert that religious principles ought to be an acceptable form of reasoning in the public sphere, that they in fact benefit the avowedly secular state. As Stout and Habermas are eager to establish, public discourse is somehow lacking if individuals cannot draw from all their ideological reference points, and I argue alongside them (as I think Arendt would) in saying all participants in an act of political engagement — theists and non-theists alike — ought to be able to advance religious positions to one another. Contesting Robert Audi and John Rawls, I maintain that individual religious identities are a fundamental component of political engagement, that they improve a body politic.

In a final concise post-script I reflect on how I have used Arendt's theory, channeling the insights I have derived from writing this thesis. Drawing from my experience of town-hall meetings and other political activities in the city of Charlottesville, VA, ${ }^{81} \mathrm{I}$ claim that action, in its purest form, cannot be viewed as a one-time silver bullet for solving particular political dilemmas, but must instead be regarded as a comprehensive disposition, in which political engagement is continually sought out. While I will not profess to have solved our current

\footnotetext{
${ }^{81}$ It should be noted that Arendt thought town-hall meeting embodied the direct communication and identity affirmation she idealized in the space of appearance. See Elisabeth Young-Bruehl, Why Arendt Matters, 129-130.
} 
political dysfunction, I conclude this post-script with some recommendations for conceptually reorienting our understanding of political engagement.

In this introductory chapter, I have detailed a portrait of Hannah Arendt's life and theory, unraveling the vita activa to uncover how political actors can revive their political deliberation. By devoting increased attention to action and the space of appearance, I have investigated Arendt's account of political engagement and her conception of how to establish an ideal polis. By pointing out two aporias in Arendt's thought I have shown how to strengthen her theory, a task I will be engaged in throughout the remainder of this thesis. Thus, I begin my project, turning to the interior composition of political actors and their effect on an act of political engagement to paint a fuller picture of the space of appearance. 


\section{Chapter Two: A Schematics of Plurality}

In the previous chapter, I introduced the work of Hannah Arendt, embracing her outlook on how citizens ought to inhabit their political space. In addition, I endorsed her thought for the way it provides resources to create an enduring but nevertheless spirited body politic, an especially pertinent objective given our contemporary governmental dysfunctions. While this first chapter clearly established that plurality is a requisite element of politics, it will be necessary to further articulate this concept's meaning, an effort I now undertake.

As was also previously indicated, plurality maintains a supreme importance in Arendt's political schema, allowing individuals to "disclose their identities" to one another, construct "webs of relationships," and eventually found the space of appearance, that ideal political locality in which a citizenry strives to build an imperishable public entity. Although political engagement and the space of appearance possesses its own intrinsic value, Arendt thinks it also endows a collective group of citizens with power or agency, buttressing their association with one another while aiding them in the pursuit of their political goals. To be sure, plurality in many ways makes human affairs a possibility, indubitably playing a key role in organizing a collected group's action and thereby reinvigorating their public discourse. And yet, Arendt's explanation of the processes by which plurality and power are forged is fragmentary at best, and she devotes minimal space to elaborating on the underlying mechanisms that drive these operations. Undoubtedly, Arendt is problematically nebulous on the specific components of plurality, warranting my extensive investigation here.

On another level, however, Arendt's flaws of imprecision cannot be avoided. While her analysis of power and society was groundbreaking in its own time, more recent thinkers and texts 
have since emerged in critical theory, not only advancing forceful critiques of her work, but expatiating on features of human life she never considered. Therefore, one of the auxiliary goals of this chapter is to update Arendt's thinking given new advents in critical thought. In doing so, I throw a new lens onto Arendt's writings, illuminating previously neglected features of her work that can be used to ameliorate the detrimental aspects of politics today.

In this chapter, I elaborate on Arendt's conception of plurality, delving into its anatomy and effects to discover what kind of political space she aspires to generate. To do this, I enter Arendt into a critical conversation with post-structuralism, beginning by juxtaposing her work to philosopher Michel Foucault to illustrate how political engagement shapes and reshapes actors. I then turn to gender theorist Judith Butler, demonstrating how one simultaneously procures agency through subjection. Finally, I contend with the work of anthropologist Saba Mahmood, arguing that an Arendtian notion of political agency must be cultivated within a particular community. By conversing with these dialogue partners, I argue that plurality acknowledges the distinct identity of each interlocutor that enters the public sphere, a conception of human togetherness that resembles a kind of pluralism in its recognition of a wide variety of disparate rationales.

It is worth noting at the outset that the post-structuralists I use in this chapter would have at least some trepidations concerning Arendt's unwavering espousal of democracy, as they are all moderately skeptical of what democratic institutions can accomplish. ${ }^{82}$ Still, their comparable perception of power relations helpfully clarify Arendt's indistinct description of plurality. ${ }^{83}$

\footnotetext{
${ }^{82}$ This is not to say Arendt does not have her own qualms with democratic institutions, but she certainly views democracy more favorably than this chapter's other interlocutors.

${ }^{83}$ While Arendt's essay "What is Authority?" in Between Past and Future argues in a post-structuralist vein, Foucault, Butler, and Mahmood remain useful for elucidating her thought. I should also mention that although I could similarly probe other tenets of action (for example, natality and freedom), lack of space prevents such an analysis here.
} 


\section{Examining Plurality}

To provide the most thorough foundation of Arendt's plurality, I now review select passages from The Human Condition. As was shown above, action is the only element of the vita activa that cannot be "imagined outside the society of men," the only activity utterly contingent on the sustained presence of "equal and distinct interlocutors." 84 On Arendt's view, individuals reveal their "unique distinctness" to one another by disclosing their identity to those around them, using their speech and action to "insert" themselves into their environment in a way that transforms their being. ${ }^{85}$ Undoubtedly, speech is the facilitator of plurality for Arendt, as she thinks it "exposes" an actor's true personality, her unique "who-ness" that contributes to political engagement. ${ }^{86}$ In one sense, Arendt thinks action composes one's being.

As an increasing number of individuals use their freedom to enter into the public sphere with one another, Arendt thinks they begin to develop what she calls "webs of relationships," a metaphor she uses to describe the connectivity of human life (both pre-political and political) as well as the framework from which action emerges. ${ }^{87}$ Existing long before one ever enters into them—-preceding their natality as she might say—-these relational "webs" form an actor's subjectivity, equipping the politically engaged individual with the capacity to engage with and reconfigure these "webs." Over time and with the perpetuation of political action, these networks

\footnotetext{
${ }^{84}$ The Human Condition, 175.

${ }^{85}$ Ibid., 177.

${ }^{86}$ Ibid., 178. As Passerin d'Entrèves notes, speech discloses "the aims and intentions of the actor while articulating the meaning of the act," allowing the actor to live in solidarity with her interlocutors. See, The Political Philosophy of Hannah Arendt, 73.

${ }^{87}$ The Human Condition, 183.
} 
of citizens accumulate and establish the space of appearance, creating a more durable public space and endowing those collected individuals with power. ${ }^{88}$

Indeed, for Arendt inaugurating the space of appearance actualizes power for that group, producing an energy that reinforces their communal association. Whereas other political forces like strength and violence can be wielded by a single individual, ${ }^{89}$ power, according to Arendt, directly correlates with the "human ability" to "act in concert," drawing from the consent of the actors within that organizational structure to maintain the space of appearance and provide an arena for speech and action. ${ }^{90}$ Yet, construing power solely as a method to bolster community is not entirely accurate, as it maintains another role in the public sphere as well.

While power's primary function is to sustain a polity and supply the "raison d'être" of politics, this is not to say it cannot be employed to achieve certain ends. ${ }^{91}$ On the contrary, Arendt thinks power equips actors with agential faculties, which can then be cultivated and directed toward accomplishing political tasks. Arendt's two notable examples of this are the rise of labor unions in Europe and the American Revolution, both of which used collective power to achieve a particular objective while focusing on establishing vibrant political engagement. Regardless of a community's accomplishments, however, the most crucial element of action for Arendt remains its aim to institute the space of appearance and reinvigorate the body politic. As should be clear from this expanded review of plurality, the disclosure of identities initiates a process that can potentially establish the space of appearance and bestow power on a collected group of individuals, making it an essential component of action. However, while this

\footnotetext{
${ }^{88}$ Ibid., 198.

${ }^{89}$ See Arendt's, "On Violence" in Crises of the Republic, 140-3 for a more thorough discussion of these forces.

${ }^{90}$ The Human Condition, 201. As Arendt also writes on this page, "The only indispensable material factor in the generation of power is the living together of people."

${ }^{91}$ Ibid., 204.
} 
coheres nicely within Arendt's own framework, it is difficult to understand how or why the processes of plurality generate the outcomes they do. For example, how do citizens derive power as a result of disclosing their identity to one another in public deliberation? Surely Arendt has more in mind here than merely enlarging a collective group into a social horde. Moreover, why must the space of appearance be perpetually recreated on Arendt's view? Unfortunately, the specific functions of the activities performed within plurality remain latent throughout her corpus, necessitating that I fill them out in greater detail. In the next section I engage the philosopher Michel Foucault to gain insight into what constitutes the web of relationships and how they contribute to political engagement.

\section{Foucault}

French philosopher Michel Foucault's genealogical method offers significant insight into Arendt's concept of plurality and consequently her political thought. My exploration will be limited to glimpsing at a concise selection of his numerous writings, focusing especially on his theory of power relations and the discursive practices that subjectivate individuals. Despite the fact that he poses his own difficulties of vagueness, he lays necessary groundwork for commencing a post-structuralist account of plurality.

A theorist of politics and historical systems of thought, Foucault is similar to Arendt in recognizing that modernity significantly altered our society. ${ }^{92}$ On his view, the modern age inaugurated a new genus of power, one that cannot be understood solely as "repressive" or as an exclusive faculty of the State. ${ }^{93}$ While this "juridico-discursive" model of power continues to

\footnotetext{
${ }^{92}$ As an aside, it is interesting to note that Heidegger was influential for both Foucault and Arendt, the latter having studied with him at Marburg and the former having interacted with many of his students.

${ }^{93}$ Michel Foucault, Discipline and Punish: The Birth of a Prison (New York: Vintage, 1979), 194.
} 
hold some validity in contemporary culture, Foucault contends that power must also be considered "productive," that it ought to be viewed as a disciplinary force that fashions the subjectivity of individuals through their "mutual relations" within a social organism. ${ }^{94}$ Accordingly, Foucault rejects the position that a subject could be fully formed prior to an encounter with power, as it is only through this array of force relations that one's subjectivity is produced and subsequently organized..$^{95}$ Foucault thinks that by taking part in these historically constructed yet immanent discourses, one in effect becomes a human being.

With his discussion of power relations, Foucault is primarily interested in how the various manifestations of "discourse" produce effects on individuals, how these "omnipresent" formative mechanisms exercise control over people's lives. ${ }^{96}$ In some cases, these discursive formations are pronounced; for example, governments undeniably shape subjects in myriad ways through an assortment of means. However, Foucault's primary ambition is not to show how particular persons wield power, but to elucidate how abstract social forces manufacture subjectivity, a process in which the potential subject's very nature is assembled by the "pre-existing" series of relations into which they are inducted. ${ }^{97}$ Through its multitudinous stratagems and various manifestations — both physical and mental—power structures social life.

\footnotetext{
${ }^{94}$ Amy Allen, "Power, Subjectivity, and Agency: Between Arendt and Foucault," International Journal of Philosophical Studies 10 (2): 134.

${ }^{95}$ Michel Foucault, "The Ethics of the Concern of the Self as a Practice of Freedom," in Ethics: Subjectivity and Truth, ed. Paul Rainbow (New York: The New Press, 1994), 290-2. In Gödel, Escher, Bach, Douglas Hofstadter discusses the Buddhist tenet of "Indra's Net," in which each life is viewed as one node of a "dew-covered net." With each distinct thread being refracted by dew, the web appears to become an endless yet interconnected set of ligatures, which corresponds to our own social connectivity. I find this analogy useful for explicating Foucault's power relations. ${ }^{96}$ Michel Foucault, The History of Sexuality, Volume 1: An Introduction, trans. Robert Hurley (New York: Vintage, 1990), 93.

${ }^{97}$ Michel Foucault, The Archaeology of Knowledge, trans. A.M. Sheridan Smith (New York: Routledge, 1972), 230. See also Michel Foucault, "Docile Bodies" in The Foucault Reader, ed. Paul Rainbow (New York: Pantheon, 1984), in which he discusses the various bodily and mental practices that discourse people.
} 
Further, Foucault regards power relations as "essentially incomplete," unremittingly renegotiating their organizational structure and "reveal[ing] new possibilities" of discourse to the subjects they engage with. ${ }^{98}$ Following this principle, discursive formations are never static, nor do they seek to unify other discourses under a monolithic regime; rather, they are marked by their "multiple dissensions," maintaining their interaction while resisting homogenization with one another. Indeed, political theorist Ian Shapiro encapsulates the essence of power relations when he calls them "hydralike," convincingly arguing that their incessant evolution "displaces" each other such that even seemingly extinct discursive forces continue to have social impact long after their apparent dissipation..$^{99}$ Thus, for Foucault power is "capillary," circulating across a social imaginary and interacting with even the most peripheral aspects of life to exert a pervasive discursive force. ${ }^{100}$

A good illustration of what Foucault means by power relations can be found in British sociologist John Hargreaves' study of modern sports culture, ${ }^{101}$ in which the latter shows how athletics maintain a seemingly inexorable influence over a social body. On the one hand, Hargreaves notes, individuals who participate in activities like football or golf are obviously formed by that discourse, as their body is literally taught how to move through their interactions with that discipline. ${ }^{102}$ Beyond these corporeal energies, however, Hargreaves reveals the cultural

\footnotetext{
${ }^{98}$ Archaeology of Knowledge, 75.

${ }^{99}$ Ian Shapiro, The State of Democratic Theory (Princeton, NJ: Princeton University, 2003), 36-8. One example of an extinct but still relevant discourse is the Enlightenment, which on Foucault's view continues to exercise control over contemporary life.

${ }^{100}$ Nancy Fraser, Unruly Practices:Power, Discourse, and Gender in Contemporary Social Theory (Minneapolis: University of Minnesota, 1989), 24.

${ }^{101}$ John Hargreaves, Sports, Power, and Culture: A Social and Historical Analysis of Popular Sports in Britain (New York: St. Martin's Press, 1986). Although rarely referenced in it, this text is clearly Foucauldian in nature.

${ }^{102}$ For Hargreaves, the most obvious example of athletic disciplinary power is the "ritual" of physical education, in which students not only employ certain "movement technologies" on themselves but also learn about rules, authority, and the threat of physical force. See ibid., 166-171.
} 
effects of sports, how they extend across social life. For him, not only do sporting events structure our home and consumer lives (by being broadcast on television and featured in advertisements), but they also symbolically divide geographic areas, inform gender as well as class stereotypes, and produce cultural icons who themselves obtain social authority. Moreover, while there is a central locus of power for athletics - typically in the form of a field or a court-Hargreaves argues that the more potent effects of sport manifest themselves at the familial, societal, and even political level. ${ }^{103}$ Indeed, Hargreaves' study on recreation shows the pervasity of power relations and its interconnectedness to other social forces, providing a captivating application of Foucauldian power. ${ }^{104}$

Comparing Foucault's reflections on social life to Arendt's enhances our perception of the way power alters an individual's being, offering a more rigorous depiction of the way Arendt's plurality resembles Foucault's power relations. While their political frameworks diverge from one another and thus present clear limits to comparison, their foundational conceptions of power exhibit striking similarities. For both Arendt and Foucault, power cannot be commanded by a single individual, but should instead be regarded as relational, pervasively manifesting itself between subjects almost regardless of their social station or occupation. ${ }^{105}$ In addition, both think power and the social force it exerts precedes the subject it shapes, and that the person who comes into contact with power will be transformed by it.

\footnotetext{
${ }^{103}$ On the political level, we can look to the quasi-ceremonial act of a US President throwing the first pitch at a baseball game as a kind of socio-political discourse of power.

${ }^{104}$ Although Hargreaves' study focuses primarily on the UK and was written almost thirty years ago, its applicability to today only seems to prove Foucault's point that power relations are nearly omnipresent and enduring.

${ }^{105}$ In an interview near the end of his life Foucault claimed that Arendt's conception of action was analogous to his power relations. For more, see Allen, "Power, Subjectivity, and Agency," 148-9.
} 
However, this is where the explicit Arendtian analysis largely concludes; by contrast, Foucault expands on the intricacies of power, delving more deeply into its precise nature in a way that exposes some of Arendt's unstated assumptions. Firstly, Foucault formulates a fuller depiction of why Arendtian relational webs precede the subject, a feature of political life they largely agree on but many writers misunderstand. While it is tempting to read the disclosure of identities and the action that results from it as finally granting power to individuals who were previously amorphous and solitary, such a reading is ill-informed and idealistic. ${ }^{106}$ On my view, this interpretation of Arendt fails to acknowledge the wide scope of her thought, pigeonholing her work as an instruction manual for revolution or a silver bullet for expediently resolving all our political dilemmas. Foucault helpfully circumvents this reading by helping us to perceive that Arendt's relational webs are in a perpetual state of reconfiguration, that the subject's explicit engagement in public deliberation does not initiate an entirely novel form of power but reshapes the relations in which they were already living. ${ }^{107}$ Through Foucault then, we see that Arendt's disclosure of identity alters the pervasive and immanent power relations in which one is situated, redirecting the subjected self toward new-ultimately political—goals. ${ }^{108}$

Furthering this point, Foucault's capillaric power is useful for detailing why the disclosure of each new identity shifts power relations and the individuals therein, as it illustrates the way social forces spread across a community as though they were webs. ${ }^{109}$ For Arendt, each

\footnotetext{
${ }^{106}$ Such readings of Arendt can be found in portions of Howard's Rule of Nobody, which I referenced in chapter one.

107 Throughout The Human Condition, Arendt is clear that action is dependent on one living in human togetherness; while she does not resemble Foucault in parlance or tone, there is a clear sense in her work that persons already inhabit these social relations by virtue of their humanity.

${ }^{108}$ Although recent studies on Foucault and bio-power forcefully problematize Arendt's strict divide between the public and private spheres — most notably, Hardt and Negri's Commonwealth (Cambridge, MA: Belknap, 2009)—I continue to find Foucault useful for illustrating Arendt's thought on the general structure and interconnectedness of power.

${ }^{109}$ Foucault even refers to power relations as "webs" with some frequency, emphasizing their "net-like organisation" and their ability to pervasively modify individuals. Michel Foucault, "Two Lectures" in Power/Knowledge: Selected Interviews and Writings, 1972-1977, ed. Colin Gordon (New York: Pantheon, 1980), 98.
} 
citizen contributes an original perspective to an act of political engagement, bestowing new claims on an organization such that the group itself cannot remain static. When a politically engaged collective inducts new citizens into its discourse, prior members are liable to respond to and interface with these new persons, interacting with these more recently disclosed identities in a way that may not transform that assemblage's objective but will undoubtedly alter their interconnectedness. ${ }^{110}$ Hence, we can see that the disclosure of identities is never a mere collection of members for Arendt, but a recognition of the many persons that constitute plurality and the political realm.

Moreover, Foucault helps to give a greater understanding of Arendt's space of appearance. As I read him, Foucault would identify the space of appearance as yet another kind of power relation. However, while the majority of his ruminations on discourse seem to imply one's passive subjection to and subsequent formation by power, the space of appearance would represent a more active domain, a desirable sphere of life in which citizens democratically determine their own lives. Although Foucault would of course consider individuals as already discoursed, the space of appearance undoubtedly signals an alteration in one's social context, a modification of the situated self. ${ }^{111}$ On the most basic level, Foucault shows how in Arendt one's enactment of power reshapes an individual and her social surroundings through the various

\footnotetext{
${ }^{110}$ An illustration of what I mean here comes from the Civil Rights Movement, specifically how the Southern Christian Leadership Conference (SCLC) had to adjust their strategy following the creation of the Student Nonviolent Coordinating Committee (SNCC), at times to the frustration of both organizations. Though they had a common political cause, their differences forced each other to reassess their respective modus operandi. For a brief overview of the relationship between the SCLC and SNCC, see Stanford's Martin Luther King Jr. papers, available at http://mlk -kpp01.stanford.edu/index.php/encyclopedia/encyclopedia/enc_student_nonviolent_coordinating_committee_sncc/. 111 The locution “situated self” alludes to Seyla Benhabib's Situating the Self: Gender, Community, and Postmodernism in Contemporary Ethics (New York: Routledge, 1992), in which she argues that individuals can challenge and subsequently alter their social context. Notably, references to Arendt pepper this monograph.
} 
interlocking discourses she partakes in, thereby gaining additional purchase on what the Arendtian citizen contributes to political action.

As can be seen, Foucault's power relations are helpful for elaborating on Arendt's perplexing description of relational webs, granting a more thorough conception of both the way disclosing one's identity inducts her or him into power relations and how social webs reify the space of appearance. Still, Foucault is not wholly adequate for explicating Arendt's thought, as his unrelenting focus on diagnosing our subjection to power leaves little room to adjudicate how agency is acquired from it, an integral feature of Arendtian plurality. ${ }^{12}$ As one commentator argues, Foucault's understanding of power is somewhat "dark" and "nefarious," leaving readers feeling "locked in an iron cage" with little to no method for augmenting the regimes that subject them. ${ }^{113}$ Not only does this predicament amplify the problems that precipitated this thesis, but Arendt's relational webs seem more amenable to selection than Foucault's, with citizens being more capable of influencing the shape of their world through democratic politics. Clearly, these objections divide our two thinkers, requiring that I turn to others to glean a better understanding of plurality. To do this, I now seek assistance from Judith Butler, using her work to uncover how one's subjection concomitantly produces agency for that person.

\section{Butler}

Although Foucault helpfully commences our post-structural engagement with Arendt, his general lack of attention to agency requires an encounter with the work of Judith Butler. As with

\footnotetext{
${ }^{112}$ While this is not to say subjection is entirely passive for Foucault —indeed, he often writes to the contrary - the ineluctability of his power relations downplay a sense of agency other thinkers highlight in greater detail.

${ }^{113}$ Allen, "Power, Subjectivity, and Agency," 144. Philosopher Charles Taylor has made similar claims in a famous critique of Foucault, wherein he argues Foucault's "neutral" account of norms makes the French philosopher's discussion of power relations disconcerting at best. See Charles Taylor, "Foucault on Freedom and Truth," Political Theory 12 (2): 152-183.
} 
the previous section, limited space prohibits me from furnishing a robust exposition of her work; thus, I focus on her assessment of the processes by which power relations simultaneously produce subjectivity and agency. Through her, I build on my analysis of Foucault, arriving at a more meticulous account of the way Arendt's plurality enacts a person's capacity to engage with the polis.

In many ways, Butler operates within a Foucauldian framework; like the French theorist, she asserts that power is not merely domineering but also generative, rigorously "forming" subjects in such a way that their existence is "dependent" on these paradoxically constraining and enabling energies. ${ }^{114}$ Also alongside Foucault, Butler thinks that subjects cannot be fully considered human apart from their engagement with power relations, that the "doer behind the deed" is "invariably constructed in and through the deed" itself. ${ }^{115}$ Correspondingly, there is no pre-subjected self for Butler, as she thinks individuals are always already "implicated" within a "matrix" of interlinked and perdurably fluid discourses by virtue of their being. ${ }^{116}$ While she echoes Foucault in these formative aspects of power, she ventures further into this line of thought, elucidating how one's subjection engenders agency.

On Butler's view, power not only forms the conditions from which the subject emerges but also provides the means for persons to enact their own power, reversing force relations such that the power once "acted on" subjects comes to be "acted by" them. ${ }^{117}$ This argument takes it most famous form in Butler's theory of gender; for her, gender cannot be regarded as a "noun" or

\footnotetext{
${ }^{114}$ Judith Butler, The Psychic Life of Power (Palo Alto, CA: Stanford, 1997), 2.

115 Judith Butler, Gender Trouble: Feminism and the Subversion of Identity (New York: Routledge, 1990), 2. It should be noted that Butler does not simply mimic Foucault's power relations, as she thinks he is especially inattentive to the psychoanalytic mechanisms of power.

${ }^{116}$ Judith Butler, Giving an Account of Oneself (New York: Fordham, 2005), 7. As with Foucault, the analogs to Arendt's natality on this point are striking.

${ }^{117}$ Psychic Life of Power, 14-5.
} 
a "set of free-floating attributes." Rather, she views it as "performative," in which individuals employ language and gestures to reiterate social norms that substantiate gender paradigms, chief among them heterosexuality. ${ }^{118}$ However, because every person exists in and contributes to this "matrix of gender relations," Butler thinks it is itself unstable, as those who come into contact with it will subsequently be able to identify their subjection, recognize its fungibility, and "coopt" these social forces. ${ }^{119}$ From this, Butler claims the subject created by power simultaneously "founds" her own agency. ${ }^{120}$

Indeed, Butler thinks performativity plays an indispensable role in forming agency, as she maintains that "the iterability of performativity" is itself a "theory of agency." 121 Since power relations are constructed by the displacement of social conventions, Butler asserts that a "resignification" (or, alternatively, a "subversive resignification") of those fictive conventions opens "gaps and fissures" that exposes a person's ability to "denaturalize" or "destabilize" seemingly immutable discourses. Thus, agency itself is contingent on the ability to act in ways that redirect or reorient these subjectivating power relations, subsequently altering the social context in which one is embedded. ${ }^{122}$

Like Foucault, Butler sheds light on Arendt's conception of plurality, specifically on how the latter's relational webs impart agency to citizens when they engage in public action. As readers will recall, Arendt holds that a multitude of individuals generate power when collectively

\footnotetext{
${ }^{118}$ For Butler, the body becomes a gender only "through a series of acts that are renewed, revised, and consolidated through time," which reinforces certain social paradigms at the expense of others. See Judith Butler, "Performative Acts and Gender Constitution: An Essay in Phenomenology and Feminist Theory" in Performing Feminisms: Feminist Critical Theory and Theatre, ed. Sue-Ellen Case (Baltimore: Johns Hopkins, 1990), 274.

${ }^{119}$ Judith Butler, Bodies that Matter: On the discursive limits of Sex (New York: Routledge, 1993), 7.

${ }^{120}$ Psychic Life of Power, 16.

${ }^{121}$ Judith Butler, Gender Trouble, 2nd ed. (New York: Routledge, 1999), xxiv.

${ }^{122}$ Ibid., 138.
} 
acting in the public sphere, allowing them to wield some semblance of influence within a particular space. This political agency is especially potent once the space of appearance has been inaugurated, actualizing power so as to preserve the body politic and allowing citizens to continually act. ${ }^{123}$ Hence, for Arendt agency springs up from "human togetherness" - indeed, our analysis of Foucault confirmed this - as she repeatedly states that power "stands in need of numbers," that agency will result only from the consent and will of the people. ${ }^{124}$

Although Arendt is clear that she looks fondly on the cohesiveness of a social group, she also writes that contemporary politics are often mistaken for any amalgamation of persons concerned about a particular socio-political issue, a phenomenon she would likely attribute to the advent of "the social." 125 On even the most cursory reading of Arendt, it is evident that power is not merely a consequence of an aggregate number of citizens. But how then does plurality generate agency?

On my view, Butler gives insight into how power stems from subjection, how one's initiation into the public sphere achieves agency. Although I rely on the work of Saba Mahmood to more fully explain this line of thought below, Butler usefully begins the conversation, demonstrating how the subject's engagement with her own "social temporality" grants political agency. ${ }^{126}$ I elaborate on this aspect of Butler's thought now, ultimately showing how our social existence provides the means to procure power.

As Butler writes in Gender Trouble, agency is the "possibility of variation on the repetition" of norms, the ability to "resignify" the forces subjecting a person to the extent that

\footnotetext{
${ }^{123}$ The Human Condition, 200.

${ }^{124}$ Crises of the Republic, 141.

${ }^{125}$ Although Pitkin's Attack of the Blob focuses especially on those manifestations of the social that were present before and during Arendt's lifetime, there is little doubt that many of these forces persist today.

${ }^{126}$ Giving an Account of Oneself, 8.
} 
imaginative ontological possibilities are revealed to her or him. ${ }^{127}$ Diverging somewhat from Arendt in focusing on how a singular individual alters her or his own subjectivity, ${ }^{128}$ Butler is correct to indicate that agency is derived from interacting with these vaguely perceptible power relations themselves, that reorienting one's comportment through specific kinds of actions grants power to the subject. The most famous example of these "parodic practices" from Butler's own oeuvre is her elucidation of the drag queen, in which the subject overtly "parodies" particular gender paradigms and thus exposes their cultural fabrication, simultaneously illuminating a method to continue resignifying those archetypes. ${ }^{129}$ When taking part in these types of activities, the subject is endowed with agential capabilities, revealing to that individual understandings of power that are analogous to Arendt's.

With Butler in mind, we can draw parallels to Arendt's thought, viewing a citizen's participation in political action or initiation into the public realm as similarly impacting the social spheres she or he occupies. In one way, Butlerian agency is exemplified in the Arendtian tenet of disclosing one's identity; in undertaking this "performative" practice and in a sense subjecting themselves to the public sphere by "beginning" to act, Arendt thinks citizens ontologically alter not only themselves but their metaphysical location within their community as well. ${ }^{130}$ For Arendt, the public realm is fundamentally constituted by the performance of these political acts, as the ability to "set something into motion"—namely, oneself as a political agent—eventually

\footnotetext{
127 Gender Trouble, 145.

${ }^{128}$ In truth, Butler pays little attention to how the subject interacts with their fellow subjected individuals to procure agency, a point that Arendt makes clear. For this reason, I use her primarily to commence the conversation on post-subjection agency, looking to Mahmood for a more Arendtian analysis of this tenet.

${ }^{129}$ Ibid., 137. As Butler later writes, "The critical task is...to affirm the local possibilities of intervention through participating in precisely those practices of repetition that constitute identity and, therefore, present the immanent possibility of contesting them." See ibid., 147.

${ }^{130}$ Throughout The Human Condition, Arendt refers to political speech as "performative" and action itself as a "performance." Although this obviously does not carry a Butlerian valence for Arendt, the similarities are apparent.
} 
produces the power that undergirds plurality. ${ }^{131}$ While the scope and parlance of Arendt and Butler differ dramatically, the underlying point between them remains: political agency arises only by interacting with our social situatedness.

Though using dissimilar vocabulary, Butler's insights clarify much in Arendt's conception of plurality. In particular, Butler helpfully outlines how power is created by political action. Still, despite Butler's usefulness in elucidating how subjection results in agency, some of the discrepancies between her and Arendt remain irreconcilable. Most prominent among these is the fact that Butler does not adequately detail how one cultivates agency within subjection; that is, how power proceeds from inhabiting a community with other persons. As I read Arendt, the web of relationships fosters agential power because of the multiplicity of actors disclosing their identities to one another in a specific political space. Following this principle, for Arendt one's political agency is predicated on occupying a field in which an individual and her fellow interlocutors can become a politically engaged citizenry, standing somewhat at odds with Butler's understanding of power as instantaneously granted to the subject that independently grasps for it. ${ }^{132}$ Put differently, Butler does not sufficiently explain how a collective group of

\footnotetext{
${ }^{131}$ Here Arendt's discussion of the American Revolution from On Revolution again becomes relevant, as the Founding Fathers performed particular actions - especially the founding of the State and the composition of the Constitution - that lent power to their polity. See especially Chapter Five: "Foundation II: Novus Ordo Saeclorum."

${ }^{132}$ Here I am primarily referring to Butler's concept of resignification. On my reading of this tenet, Butler thinks agency is conferred on actors precisely when they undertake a particular resignifying act. For example, Butler thinks the drag queen attains agency at the moment of her norm-subverting performance, as the presentation itself repositions those "congealed" social conventions. While Butler does occasionally account for the fact that these performances must be undertaken perpetually within a specific context to produce lasting change, her emphasis on the "rupture" created by enacting one's agency detracts from the way organized groups can develop and deploy their collective action in the public sphere, a clear deviation from an Arendtian framework. For an analysis of Butler's failure to account for communal action and her overemphasis on the significance of individual agency, see Lois McNay, "Subject, Psyche, and Agency: The Work of Judith Butler," Theory, Culture and Society 16, no. 2 (1999): 175-193.
} 
actors develop and then utilize their agency within plurality, a necessary component of an Arendtian outlook. ${ }^{133}$

To overcome these obstacles, I seek assistance from Saba Mahmood. With her Politics of Piety - an ethnographic report and anthropological examination of the Egyptian mosque movement-Mahmood shows how habitually partaking in discrete actions post-subjection inculcates certain norms in particular groups of individuals, instilling virtues in those social actors and allowing them to advance their agency through that conceptual framework. Therefore, Mahmood incorporates a community-centric component to post-structuralist agency, claiming that by inhabiting a specific society the situated self achieves the ability to engage with politics and other cultural institutions. As my final link in this post-structuralist exposition of Arendtian plurality, Mahmood brings the diverse perspectives of these thinkers into focus.

\section{Mahmood}

Essentially, Saba Mahmood's ethnography of the Egyptian mosque movement contextualizes the ways agency is refined within a particular discursive formation. Using her work, I show that habituated action within a distinct community produces the conditions in which vibrant, Arendtian-style political discourse can be reified. Although she departs from our previous interlocutors in significant ways, she provides invaluable resources for thinking about the political implications of plurality.

\footnotetext{
${ }^{133}$ My report of Arendtian agency should not suggest that she only allows for cultivated agency, as spontaneity plays a clear role in engaging with the polis. However, my juxtaposition of Arendt to Mahmood is intended to signify that the former thinks political action brings a specific kind of person into being, forming the kind of self that can undertake spontaneous political acts.
} 
In many respects, Mahmood is a post-structuralist herself, concurring with Foucault and Butler in maintaining that power is not merely suppressive but also generative of subjectivity. ${ }^{134}$ Following especially after Butler, Mahmood posits a complementary theory of performative agency, agreeing with the author of Gender Trouble in asserting that agential potency is derived from the parameters of one's discursive conditions. Yet, Mahmood also diverges from Butler's critical theory, disagreeing that agency necessarily leads to a "resistance" of norms. Rather, she thinks norms must be "inhabited," lived out in the life of the individual and cultivated in such a way that they come to be constitutive of "the very substance of [the subject's] intimate, valorized interiority." 135 In this way, norms are "immanent" for Mahmood, repeatedly shaping the “topography of the self" through the various actions taken up by those persons. ${ }^{136}$

Further expanding on her theory of discursive formation, Mahmood rejects a deontological moral worldview, instead holding to a more Foucauldian "positive conception of ethics," wherein goodness is constituted by the "practical activities that are germane to a certain way of life." 137 Within the bounds of this conceptual scheme, ethics can be seen as a series of techniques that form the individual into a particular kind of self, as a set of practices a person must undergo to develop discrete skills and dispositions. To explain this principle, Mahmood employs the illustration of a virtuoso pianist, who recurrently subjects herself to pain and hierarchy to be able to play "with mastery," an enterprise that exemplifies "docility." 138 While

\footnotetext{
${ }^{134}$ Saba Mahmood, Politics of Piety: The Islamic Revival and The Feminist Subject (Princeton, NJ: Princeton University, 2005), 17. Regarding Mahmood's post-structural leanings, it is notable that one of her mentors is Talal Asad, a cultural anthropologist operating in a similar vein with all these thinkers.

${ }^{135}$ Ibid., 22-3.

${ }^{136}$ Ibid., 24.

${ }^{137}$ Ibid., 27. Ultimately descending from Aristotle but differing from other types of virtue ethics, Mahmood's ethical framework looks to ask "not what a particular ethical theory means, but what it does [to the subject]."

${ }^{138}$ Ibid., 29. In this way, Mahmood views subjection as pedagogical.
} 
Western liberal democrats might typically view this form of subjection as negligent passivity, Mahmood claims that agency can only be fully comprehended if one understands the "semantic and institutional networks" it sprang from; in other words, "agency must be explored from within the grammar of concepts within which it resides." 139 Indeed, for Mahmood power is derived from within the institutional structures in which we exist, a principle exhibiting key similarities to Arendt's thought.

Foucault's framework for ethics will indeed greatly influence Mahmood's theory of agency, as she thinks the type of activities a group pursues and the power they reinforce through those activities is ineluctably linked to the way persons are formed. On Mahmood's view, the actions a particular group engages in are themselves constitutive of the "architecture of the self," incessantly forming the subject's innermost being. ${ }^{140}$ This principle stems from philosopher Pierre Hadot's “spiritual exercises," an ancient Greek “conception of life and ethics" in which subjects use various physical, discursive, or intuitive practices to transform their interior selves. ${ }^{141}$ When viewed through this lens, campaigns like the mosque movement become more intelligible, with the multitudes of rituals conducted by participants - especially prayer, attending lectures, and veiling — giving the self its "proper form," shaping persons as they engage with the collective. $^{142}$

Keeping Foucault, Butler, and Hadot in the background, Mahmood then ruminates upon the Aristotelian theory of habitus. Undoubtedly drawing on but ultimately disassociating herself

\footnotetext{
${ }^{139}$ Ibid., 34.

${ }^{140}$ Ibid., 120-1.

${ }^{141}$ Ibid., 122. A French historian of philosophy, Hadot is well-known for positing that the ancients saw philosophy as a bios (way of life), as a way to form rather than inform.

${ }^{142}$ Notably, these formative actions create the subject while forging communal bonds within a shared social space, upbuilding that community not unlike Arendt's space of appearance. See ibid., 131.
} 
from a Bourdieusian account of this tenet, ${ }^{143}$ for her the term habitus signifies a pedagogical model of discursive formation, one in which a human being diligently enriches a specific virtue through "human industry, assiduous practice, and discipline," partaking in these actions so intently that it "becomes a permanent feature of a person's character." 144 By repetitively engaging in a particular compendium of external activities, Mahmood thinks one's interior behavior "comes to be regulated by the habitus," enabling that person to advance further instantiations of these actions and perpetually improve the self. ${ }^{145}$

While the notion of habitus clearly carries a devotional valence for Mahmood and the women of the mosque movement, it can also be understood as a mechanism that equips actors with methods to better cultivate their interiority. Through "constant vigilance and monitoring" of these particular practices, individuals acquire faculties previously unknown to them, granting themselves new capacities and allowing them to take part in activities that could not have been accomplished prior to their interaction with these formative processes. ${ }^{146} \mathrm{With}$ this interpretation of social formation, Mahmood shows that enacting the agency of persons requires drawing from the contexts in which they exist, consistently forming themselves such that they can have a greater effect on their society.

Mahmood's description of the way agency is developed and deployed within a particular discursive tradition confers new perspectives on plurality not found in Foucault or Butler, probing the notion that the subject obtains agential potency by cultivating a specific kind of self

\footnotetext{
${ }^{143}$ As Mahmood writes, one can hardly use the word habitus without acknowledging the work of French sociologist Pierre Bourdieu, who defined the term as the series of dispositions that permeate down and shape a distinct agent's moods and motivations.

${ }^{144}$ Ibid., 136.

145 Ibid., 137.

${ }^{146}$ Ibid., 139.
} 
within a particular community. Although Mahmood thinks post-subjection agency is refined through the habitus and is thus extremely individualized, she, like Arendt, illustrates that this enriching of power necessarily takes place within a discrete conceptual apparatus, that the activity of acquiring agency is aided by interacting with those who are similarly subjected. To make this case, I must delineate why Arendt regards the contribution of other interlocutors in political action as indispensable, looking to obscure but critical aspects of her work to stipulate where her and Mahmood cohere.

Arendt's account of judgment is helpful for elucidating this point, as it bears heavily on her understanding of the way power results from something like subjection into plurality. For Arendt, action — and subsequently, power —is dependent on a citizen's ability to judge, on one's aptitude for adjudicating between particular courses of action and implementing them in the public sphere. ${ }^{147}$ This "political ability" necessitates being able to "see things not only from one's own point of view but from the perspective of all those who happen to be present" in a community, thereby "orient[ing]" that political agent and enabling him or her to better contribute to a manifestation of power. ${ }^{148}$ On Arendt's view, the activity of judging reveals the fact that citizens live in a common world, one in which their speech and action become more formidable when they interface with those who have similarly consented to be governed. Action is accordingly strengthened by looking to the particularity of each citizen, discursively engaging with and drawing from the specific wills and intentions of distinct interlocutors to make one "the

\footnotetext{
${ }^{147}$ This comprehension of judging stands in distinction to Arendt's other sense of judgment, which she describes as a retrospective faculty of historians and poets. See Passerin d'Entrèves, The Political Philosophy of Hannah Arendt, 103. ${ }^{148}$ Between Past and Future, 218. For Arendt this aspect of judging is related to the ancient Athenian notion of phronesis, which she translates as "insight" and distinguishes from the "wisdom of the philosopher." As Arendt writes on page 230 of this text, "Man's reason...can function only if he can make 'public use' of it."
} 
representative of everybody else." 149 Thus, political agency is improved when one encounters as many perspectives as possible, granting that individual an "enlarged mentality" to better upbuild a collectively acting body. ${ }^{150}$

In looking to Mahmood while keeping Arendt's account of judgment in mind, we can acquire a fuller appreciation for the process by which political power is strengthened through interacting with one's fellow citizens. Throughout Politics of Piety, Mahmood is clear that agency is not mechanistically bestowed on subjects by merely professing their Islamic faith. Nor can attending one particular dars (lesson) singularly catalyze the alteration of one's interior architecture. Rather, in reading Mahmood, it would appear that crafting a particular kind of self and generating the agency that follows from it - a seemingly individualistic task - in actuality requires repetitively engaging with other religious devotees and the $d \bar{a}$ ' $i y \bar{a} t$ (religious teachers) who guide them, deeply immersing themselves in these pious communities to bring their ontological ideal into being. ${ }^{151}$

This principle is made clearer in examining one of the dars Mahmood visited. During a lesson on Islam and gender relations, Hajja Samira and other leaders were repeatedly challenged by numerous attendees, who debated the dā 'iyāt's social prescriptions not only on the basis of Islamic doctrine but on what practices would be sensible in one's daily life. ${ }^{152}$ Rather than passively absorbing these messages, the women of the $d a$ 'wa movement discursively reasoned

\footnotetext{
${ }^{149}$ Ibid., 237-8. On Arendt's view, representative thinking leads to more "valid" political judgments.

${ }^{150}$ Arendt borrows the notion of an "enlarged mentality" from Kant, exploring it more thoroughly in her Lectures on Kant's Political Philosophy, ed. Ronald Beiner (Chicago: The University of Chicago, 1992). See especially page 73.

${ }^{151}$ Relevant here is Mahmood's understanding of the teleological component of Foucault's ethics, which for the women of the mosque movement stipulates that constructing one's ethical self is primarily attempting to mimic "the exemplary conduct of the Prophet and his Companions." See Politics of Piety, 31.

${ }^{152}$ For the majority of the dialogue, the discussion revolved around how men and women are to maintain an appropriate amount of distance while undergoing mundane social activities. See ibid., 101-105.
} 
with their fellow interlocutors, earnestly discussing and attempting to persuade authority figures and equals alike to better understand how to bring the exemplary self into being. ${ }^{153}$ Thus, while it is true that the process of self-formation is ultimately initiated by a singular individual, a more comprehensive analysis of Mahmood's work reveals that the collective one inhabits plays an essential role in reinforcing and contributing to the development of one's agency.

In my judgment, a similar phenomenon takes place in Arendt: for the Arendtian political actor, power is not automatically imparted to an amalgam of citizens - those unthinking quasi-political collectives she elsewhere refers to as "the social"- but results only from their conscientious communal interaction, from their attempts to enlarge their association and thereby gain the ability to make more sound political judgments. Therefore, not unlike Mahmood, for Arendt the establishment of a more robust political agency requires including as many citizen's perspectives as can prudently guide a particular group's action, expanding the purview of their discourse with the acceptance of a diverse range of viewpoints. ${ }^{154}$ In this way, Mahmood elaborates further on the power produced by "sharing-the-world-with-others," as she provides an additional description of the way engaging with other subjected individuals fosters agency.

Furthermore, Mahmood's concept of the habitus elucidates how Arendt thinks perpetually participating in political action shapes one's interior being, thereby making one a more political agent and providing resources to reify a durable public sphere. Recall that for Mahmood, habitus signifies that agency can be conceived as a particular "modality of action,"

\footnotetext{
${ }^{153}$ For another perspective on a woman of the mosque movement using her dialogical interactions to inform her agency, see ibid., 176-180.

${ }^{154}$ Arendt's principles of forgiveness and making promises undoubtedly aid citizens in attending to potentially problematic political viewpoints, as these tenets allow citizens to "control, if not eliminate, the risks associated with action." While the dangers that correspond to taking diverse social opinions into account are legitimate, this does not seem to override Arendt's understanding of action as inclusive. See Passerin d'Entrèves The Political Philosophy of Hannah Arendt, 89.
} 
one that reshapes a subject's interiority when specific activities are consciously ${ }^{155}$ and consistently undertaken. ${ }^{156}$ Correspondingly, for Arendt a citizen's repetitious engagement ${ }^{157}$ in public deliberation - undoubtedly one modality of action - transforms that person, reorienting one's ontology so that she or he is constitutive of a collectively acting political body. ${ }^{158}$ While the women of the mosque movement subject themselves to certain religious institutions to cultivate their piety, Arendtian political actors must similarly engage in their variation of subjection (political action) ad infinitum, as the perspective they contribute to the public sphere is vital for the continuous generation of the space of appearance and political power. Although Mahmood is much more articulate in describing these functions and their significance for her project, she opens up new ways to talk about plurality, lending a greater understanding of how participating in human affairs shapes both citizens and their community. ${ }^{159}$

To be sure, Mahmood's post-structuralist account of agency clarifies much in Arendt's plurality, particularly in how perpetually interacting with one's community strengthens that citizen's political power. Whereas Mahmood focuses primarily on contextualizing the way Muslim women become pious devotees, Arendt's analysis draws similar attention to how a collective attains agency by engaging with their fellow citizens, habitually disclosing their identities to overhaul their political environment and become politically engaged individuals. While Mahmood does present some roadblocks to uncovering a completely Arendtian view of

\footnotetext{
${ }^{155}$ Mahmood argues that the habitus entails participating in certain external activities to transform one's interiority, what Foucault called "technologies of the self." See especially Politics of Piety, 137-9.

${ }^{156}$ Ibid., 157.

${ }^{157}$ The Human Condition, 187.

${ }^{158}$ Passerin d'Entrèves, The Political Philosophy of Hannah Arendt, 79.

${ }^{159}$ As can be seen, Mahmood's group-oriented political action stands in somewhat stark contrast to Butler's individualistic conception of agency.
} 
public life, ${ }^{160}$ she undoubtedly grants a more thorough understanding of the way a community engenders their power, which will have considerable implications for the kind of politics that will emerge from plurality.

\section{Plurality Reconsidered}

In this chapter, I have nuanced Arendt's political thought, engaging her with the post-structuralists to show how plurality situates equal and distinct interlocutors into webs of relations, bolsters their communal association, and eventually produces power. Beginning with Foucault, I found that power relations resemble Arendt's relational webs, her disclosure of identities similarly "subjecting" citizens into particular discourses. Next, Butler revealed that individuals shift the forces that subject them by interacting with power relations, and I paralleled her work to Arendt's to show how entering the public sphere manifests agency for distinct persons.

Finally, Mahmood illustrated how agency is cultivated within a discrete community, how perpetually undertaking certain kinds of actions "consolidates" norms for that individual and transforms him or her into a particular kind of person. In viewing political engagement as a kind of habitus - one in which the regulative actions of public deliberation shapes one into a more Arendtian political agent-I demonstrated how citizens remake themselves into more engaged political actors, simultaneously altering their citizenry such that it establishes the space of appearance. Through these thinkers, I have explicated the underlying mechanisms of plurality,

\footnotetext{
${ }^{160}$ In particular I have in mind the critique advanced by political theorist Andrew March, who contends that Mahmood's work may be too habitus-laden; that is, she assumes that all religious communities conceive of their faith in this same Aristotelian mode. Most importantly for March, this shortchanges the way Muslims could be constructively included in a democratic political project. See his "Speaking about Muhammed, Speaking for Muslims," Critical Inquiry 37, no. 4 (Summer 2011): 806-821.
} 
granting a fuller conception of the process by which actors reify their ideal political space and supplying a method for ameliorating the current defects in our public dialogue.

What kind of politics does this fuller account of plurality inaugurate? What kind of political space does Arendt hope it will generate? Given what plurality contributes to her vita activa, I will argue that Arendt's ideal body politic is one that is conscious of the shifting matrices of power that exist between citizens, one in which individuals interact with and draw from the numerous relational webs within that space to generate power. While this conception of politics obviously requires an engaged citizenry, acknowledging plurality also adjusts the way persons interact with their fellow citizens.

Interestingly, Butler has reached similar conclusions in reading Arendt. In an essay on Zionism and how a diverse group of people can cohabit a common political space, Butler rightly posits that "heterogeneity" is an "irreversible condition" of Arendt's social and political schema, and that attempting to neglect the assortment of actors in a polity is akin to withdrawing from politics altogether. ${ }^{161}$ In Arendt's approach — and Butler's, for that matter-plurality is unique in that it does not institute a "single defining principle" of political actors, thereby refusing to dictate who can contribute to political discourse. ${ }^{162}$ Following this premise, plurality can be conceived as a dynamic process, one in which the particularity of citizens is not homogenized into a general horde but infinitely differentiated, subsequently making "new modes of

\footnotetext{
${ }^{161}$ Butler draws this principle from Arendt's Eichmann in Jerusalem, which claims one of the chief atrocities the Nazis committed was attempting to choose with whom to cohabit the earth. See Judith Butler, "Is Judaism Zionism?" in The Power of Religion in the Public Sphere, eds. Mendieta and Vanantwerpen (New York: Columbia University, 2011 ), 83. ${ }^{162}$ Ibid., 84. As Butler similarly argues in this text, I remain ambivalent regarding the fact that for Arendt, and for our wider political culture, it would seem, inclusion into plurality is offered exclusively to citizens. Especially in a contemporary American context, we may want to extend plurality to those non-citizens who substantially contribute to political life as well, a line of thought I unfortunately cannot take up here.
} 
pluralization" possible. ${ }^{163}$ Such an understanding of plurality recognizes that difference cannot be "overcome," but can only be inhabited by persons within that community, lived out and negotiated in their own deliberation to establish a more productive political dialogue. ${ }^{164}$

In essence, Arendt's plurality calls on citizens to embrace the "different configurations of personhood" that constitute the public sphere, welcoming these disparate voices into our relational webs to attain more perspective on our human affairs, ultimately for upbuilding the polis. ${ }^{165}$ As we saw with Arendt's account of judgment, attending to a polity's different modes of being solidifies the power that group founds with action; consequently, political discourse is hampered if interlocutors are marginalized or restricted from offering their genuine political opinions. Thus, on an Arendtian view individuals ought to be able to disclose all those aspects of their identity that can constructively contribute to our public deliberation, not allowing social convention or governmental impositions to invalidate their arguments and thereby impugn plurality. ${ }^{166}$ While there will undoubtedly be limits as to what reasons can be appropriate when introduced in public debate - particularly those that contradict the Arendtian principles of respect, solidarity, and freedom—-plurality requires embracing this ethos of inclusivity, lest the vibrancy of our political bodies be threatened. ${ }^{167}$

In this way, I contend that an Arendtian conception of plurality leads to a politics that is cognizant of the many types of citizens that inhabit that space, sincerely attending to their

\footnotetext{
163 Ibid., 85.

164 Ibid., 87.

${ }^{165}$ Politics of Piety, 120. Although Mahmood's political project differs from Arendt's, her understanding of self-formation leads her to a similar understanding of the multiplicity of individuals that inhabit the public sphere.

${ }^{166}$ While Arendt is clear that goodness, love, and compassion ought to remain private, this should not preclude certain kinds of individuals, particularly religious persons, from engaging in political action. See The Human Condition, 242.

${ }^{167}$ As Butler argues, to restrict others from entering the public sphere would be tantamount to destroying social life. See The Power of Religion in the Public Sphere, 88.
} 
individual political reasons such that additional perspectives are lent to action. Following what she takes to be a decidedly Athenian model of political interchange, Arendt thinks it is the responsibility of each citizen to "act as bodyguards" to their interlocutors, allowing them to express their genuine political reasons to undergird their communal power. ${ }^{168}$ Indeed, this political project does resemble a kind of pluralism, one that seeks to "celebrate and enhance" the equality and distinction of actors who immerse themselves in political discourse while still acknowledging the organizational structures and power that constitute our public space. ${ }^{169}$

As this chapter has made clear, Arendt's conception of plurality and her ideal political space accept the radical diversity of persons, with individuals drawing on the many perspectives of the citizens that make up their body politic to solidify their power. Given this outlook, it would seem that a reinvigoration of our politics on Arendtian terms would require the inclusion of a multitude of viewpoints, a conception of political engagement that would refuse to relegate a citizen's political argumentation to the periphery of action. In my judgment, this principle ought to apply to interlocutors who put forward religious arguments - both from a devotional and non-devotional standpoint — and I would maintain that from an Arendtian stance, individuals ought to feel able to advance political debate through their religiously grounded reasons. While Arendt does not explicitly discuss this line of thought in her work, my exposition of plurality has shown that her conception of politics remains inclusive of the many varieties of outlooks that exist in the public sphere. I elaborate on this issue in the ensuing chapter, showing how in an Arendtian view of democratic political engagement is in need of a diverse range of voices, including religious ones.

\footnotetext{
${ }^{168}$ Quoted from Xenophon's Hiero. See Arendt's Crises of the Republic, 149.

${ }^{169}$ Chantal Mouffe, The Democratic Paradox (New York: Verso, 2000), 19.
} 
In this chapter, I have expanded Arendt's tenet of plurality, uncovering a vital aspect of her vita activa. In doing so, I also opened her thought up to new analyses, showing how her political framework necessitates engagement from myriad interlocutors. In the following chapter, I contextualize this feature of Arendt's thought, contending that political argumentation continues to be valid even if citizens operate from a specialized vantage point. Putting Arendt in dialogue with Jeffrey Stout and the recent work of Jürgen Habermas, I argue that religion can play an essential role in political engagement, assisting in the creation of a more engaged polis overall. Through this investigation, my aim is not to turn democracy on its head, but to enlarge its purview, to demonstrate how making our democratic discourse more inclusive can generate resources to improve our politics. 


\section{Chapter Three: Religious Commitment and Public Deliberation, An Arendtian Approach}

An Arendtian understanding of public life necessitates enthusiastic engagement from a multitude of individuals, who draw on their collective speech and action to generate the space of appearance and political power. As chapter two has shown, one of the implications of Arendt's thought is the extent to which plurality entails being receptive to a wide variety of viewpoints. To be sure, Arendt's political framework is marked by a refusal to exclude one who seeks to enter into dialogue with another citizen, as she thinks a body politic obtains more power by recognizing and incorporating manifold perspectives into their public discourse. Put another way, chapter two elaborated on what Arendt means when she writes that the "only limitation" to action is the number of citizens ardently participating in that endeavor. ${ }^{170}$

However, it is clear that this is not our reality, as the alienation of certain kinds of voices is a commonly encountered political phenomenon. This is especially true of religion, which is ignored in political engagement in a wide array of settings. On one level, this is a widely accepted tenet of our current governmental procedures; for example, we could hardly omit the separation of church and state or the Establishment Clause from our American context. Nor should we aspire to, as these doctrines are indispensable for maintaining the neutrality and fair governance we liberal democrats (to whatever version of that paradigm we assent to) value.

Indeed, contemporary democrats are right to be wary of something like theocracy, for it exemplifies those forms of political domination that gave rise to our modern governmental structures in the first place. As American citizens, we ought to resist totalizing religio-political frameworks, as their utopian social goals are often counterintuitive to our conceptions of justice

\footnotetext{
${ }^{170}$ The Human Condition, 201.
} 
and human rights. And yet, unconditionally excluding religion from political discourse - an activity oftentimes propped up by ideological fervor itself — can be problematic as well, leading to the excessive restriction and devaluation of what religion could contribute to public debate. ${ }^{171}$ This hampers the overall state of our political engagement, narrowing the range of resources we are permitted to use in the public sphere. Following an Arendtian framework, I think democratic citizens ought to be capable of remaining cooperative despite their diverse conceptions of the sacred or the good, continuing to be interactive even if the only thing they agree on is that they all care deeply for their polis. My aim in this chapter is to mediate this divide, to examine the role of religion in public dialogue from an Arendtian standpoint and to show that it can be valuable in our political deliberation.

Following my analysis in chapter two, here I contend that religious interlocutors and their religiously based arguments are valid in political speech and action, that the democratic health of a polity is in need of these collaborators. More specifically, I offer two central arguments: firstly, I affirm that including religion in political discourse is a necessary result of Arendt's plurality, that this degree of inclusivity is an unavoidable consequence of her schema. Secondly, I assert that religion has a functional purpose in democratic politics, providing resources and reasoning strategies otherwise unavailable to an abundance of citizens. To make this case, I rely on Jeffrey Stout and the recent work of Jürgen Habermas, two philosophers who claim that religious reasons can be valid within a political body and can consequently improve the polis in which devotees reside. While I concur with these thinkers in claiming that faith-based rationale cannot be utterly unconstrained in liberal democracy, their inclusion of religion in public life gets us

\footnotetext{
${ }^{171}$ For an overview of recent governmental restrictions on religion in politics, see David M. Ackerman, "The Religious Freedom Restoration Act: Its Rise, Fall, and Current Status," available online at http://www.justice.gov/sites/default /files/jmd/legacy/2014/05/30/crsrept-1992.pdf.
} 
beyond the stultifying impasse we face today. In one sense, this chapter's goal is to more closely examine how religious citizens best "perform" their democratic role, ${ }^{172}$ and ultimately I hope to show the resources an Arendtian notion of political engagement can offer to contemporary individuals.

Before delving directly into this chapter, it should be mentioned that both of my primary dialogue partners are themselves secular, not devotionally identifying with any faith-based group. As such, my argument does not follow a theological course. Nor does it need to. Too often in political debate, religious justifications are cast aside and accused of being grounded solely in belief. Habermas and Stout helpfully sidestep this charge, showing the valuable resources religion introduces to the political sphere as well as the necessity of fostering diverse perspectives in democracy.

To offer just two additional caveats, I should note that Arendt rarely discusses religion in political engagement, an oversight in her work others have scrutinized in great detail. ${ }^{173}$ Nevertheless, my analysis in this thesis follows the ramifications of plurality rather than what is explicitly featured in her work, making my project Arendtian rather than merely Arendt's. ${ }^{174}$ Finally, while plurality could be extrapolated to discuss a number of other political matters - including debates on sexual orientation, environmental issues, etc. - this chapter focuses solely on religious argumentation in the public sphere. With that, I outline the arguments of those who consider religion unbefitting for political interchange.

\footnotetext{
${ }^{172}$ Robert Audi and Nicholas Wolterstorff, Religion in the Public Square (London: Rowman \& Littlefield, 1997$), 67$. While Wolterstorff informs my argument in this chapter, I find Habermas and Stout more relatable to Arendt's thought.

${ }^{173}$ For a detailed account of Arendt's conception of religion and her "faith" in the polis, see James Bernauer, "The Faith of Hannah Arendt" in Amor Mundi: Explorations in the Faith and Thought of Hannah Arendt, ed. James W. Bernauer (Boston, MA: Martinus Nijhoff Publishers, 1987), 1-28.

${ }^{174}$ Dana Villa argues Arendt is not necessarily averse to religion, only to its "otherworldliness." See his Public Freedom (Princeton, NJ: Princeton University 2008), 97.
} 


\section{Religion Restricted in the Public Square}

Although the majority of Americans identify with one faith-based group or another, religion in politics has long been a fraught concept. ${ }^{175}$ Unlikely to change any time in the near future, the role of religion in public life has been a consistent source of conflict throughout our history, frequently producing violence of various kinds. Even with the supposedly authoritative pronouncements handed down by the courts, the near-constant renegotiation and fluctuation of religious liberty in American political and legal structures attests to the significance of this matter. At present, it seems that religion's influence in the public sphere is dissipating, complicating how some citizens feel they can best contribute to political engagement. ${ }^{176}$

Mainstream voices do little to moderate this issue, as many policy experts and pundits categorically condemn any usage of religion in political discourse. On the extremist end, institutions like the Freedom from Religion Foundation and those associated with the New Atheist movement declare that any modicum of spirituality advanced in the political process transgresses against Western democracy's commitment to neutrality. ${ }^{177}$ Using a series of scare tactics, they claim the "cherished" Enlightenment doctrine of church-state separation is in constant threat by the infiltration of "irrational" religiosity, an argument devolving into culture wars at best, and a clash of civilizations at worst. ${ }^{178}$ While this radical but increasingly popular position could be refuted with relative ease, there are a number of sophisticated arguments for

\footnotetext{
${ }^{175}$ See the Pew Research Center's Religion and Public Life Project for specific figures, available online at http://religions.pewforum.org/reports.

${ }^{176}$ Pew Research Center, "Public Sees Religion's Influence Waning,” available online at http://www.pewforum.org/2014. /09/22/public-sees-religions-influence-waning-2/.

${ }^{177}$ For a brief overview of this position, see Sam Harris's The End of Faith (New York: Norton, 2005), especially ch. 5 ("West of Eden"). Of course, Harris is not representative of atheists or non-theists in America.

${ }^{178}$ See http://ffrf.org/about for the mission statement of the Freedom from Religion Foundation.
} 
the exclusion of religion from public affairs as well. I elaborate on two such positions now, looking to the arguments made by the philosophers Robert Audi and John Rawls. Although both Rawls and Audi judge that religion should be constrained in entering political discourse, their well-reasoned disputations provide a basis for me to offer my own view on the matter.

\section{A. Robert Audi}

An ethicist by training, Robert Audi's recent work has taken up the question of what position religion should play in public life, and he has asserted that "citizens in liberal democracies should exercise restraint on public employment of religious reasons." "179 For Audi, this contention is not necessarily based on legal justifications- - he takes the Establishment Clause as a given - but on what it means to satisfactorily play the role of a citizen, which in his view entails offering widely acceptable logic for one's political positions. Put another way, Audi believes "responsible" political engagement remains rational and non-coercive, relying only on the "persuasion" of one's rationalization "as a means to achieve cooperation." 180 This logic aims to be widely applicable, as he thinks any conscientious citizen will consent to and endorse only those rules and regulations that can be justified on secular terms. While Audi does not suggest an abandonment of religious motivations in politics, he is clear they cannot be satisfactory on their own accord to justify policies.

Systematizing these ideals, Audi then puts forward two criteria he expects will appropriately guide one's use of religion in politics. To begin, he introduces his "principle of secular rationale," which states that one has an obligation "not to advocate or support any law or

\footnotetext{
${ }^{179}$ Hugh Baxter, Habermas: The Discourse Theory of Law and Democracy (Stanford, CA: Stanford University, 2011), 193.

${ }^{180}$ Religion in the Public Square, 16.
} 
public policy that restricts human conduct, unless one has, and is willing to offer, adequate secular reason for advocacy or support." ${ }^{181}$ With this proposition, Audi argues the political reasons one puts forward ought to be justifiable to those who profess no religious belief, reasons he thinks will still be tenable for religious people and will have the residual benefit of fostering goodwill among all citizens. In this way, Audi affirms that only secular rationale can achieve validity in the public square.

The second doctrine Audi puts forward is his "principle of secular motivation," which stipulates one ought to "abstain from advocacy or support of a law or public policy that restricts human conduct, unless one is sufficiently motivated by (normatively) adequate secular reason." ${ }^{182}$ With this policy, Audi argues that even one's endorsement of a particular public action must itself be motivated by secular justifications, and that religious rationalizations must be accompanied by nonreligious arguments if they are to attain legitimacy. While a number of preliminary objections could be raised to these two contentions, I abstain from this endeavor at present, turning to John Rawls' more palatable (albeit still unduly restrictive) conception of religion in public life.

\section{B. John Rawls}

One of the most famous political philosophers in the liberal tradition, the latter part of John Rawls' career focused much on how citizens ought to engage with their democratic institutions, in addition to what resources they should be able to rely on given their multitudinous

\footnotetext{
${ }^{181}$ Ibid., 25, original emphasis.
}

${ }^{182}$ Ibid., 29, original emphasis. 
and occasionally contradictory belief systems. ${ }^{183}$ Chiefly concerned with establishing a defensible notion of justice and fairness, Rawls seeks to promote social cooperation through what he calls "reasonable pluralism." For Rawls, reasonable pluralism requires that no “comprehensive doctrine" - those irreducible moral outlooks (especially religious ones but secular forms as well) countless people believe and wish to base their political decisions on-be regarded as credible in political discourse, as these are simply not "appropriate" motivations within a freestanding conception of public reason. ${ }^{184}$ Assuming most persons possess some version of these "irreconcilable religious, philosophical, and moral doctrines," Rawls attempts to find a resolution to this dilemma, inquiring as to what types of cognitive commitments can be taken into consideration in our political discourse without dividing us and making us unable to productively inhabit a political space.

For Rawls, this predicament can be solved with a political body's commitment to only regard reasons as valid if no "reasonable person" could reasonably reject them, to only justify claims that align with the neutrality of a liberal democracy. ${ }^{185}$ On his view, our reasons for laws or policies should be valid irrespective of our comprehensive doctrines, and he refutes the notion that a nation's political values can be ordered piecemeal to satisfy the context from which particular citizens emerge. If a polity follows this principle, Rawls thinks their political rationale avoids being "manipulated," allowing all citizens to objectively evaluate a set of reasons and

\footnotetext{
${ }^{183}$ Though I take issue with much of Rawls' thought in this chapter, he and Arendt would agree on a number of points, not least of which the fact that democracy helps human beings navigate a world lacking in "ultimate truth." See Johan van der Walt, "Law and the Space of Appearance in Arendt's Thought" in Hannah Arendt and the Law, eds. Marco Goldoni and Christopher McCorkindale (Oxford, UK: Hart Publishing, 2012), 68.

${ }^{184}$ John Rawls, Political Liberalism (New York: Columbia University, 1993), 135. Rawls thus offers a more inclusive theory than Audi, claiming there are also secular comprehensive doctrines that are untenable in political discourse. ${ }^{185}$ Ibid., 50.
} 
reciprocate their own under the auspices of the impartial state. ${ }^{186}$ Therefore, Rawls argues for our political expression to be undergirded by a common political reasoning.

Perhaps realizing how restrictive this social contract theory is to religious and other moral outlooks, Rawls adds what he calls a "proviso," claiming one is permitted to "introduce into political discussion at any time our comprehensive doctrine, religious or nonreligious, provided that in due course, we give properly public reasons to support the principles and policies our comprehensive doctrine is said to support." 187 With this "wide" view of public political culture, Rawls contends citizens are in a position to use any and all reasons that appeal to them, on the condition that their comprehensive justification is eventually translated and expressed in generally accessible (read: secular) terms. Consequently, for a claim to be politically viable in Rawls' view it has to comport with "those political conceptions that are reasonable for a constitutional democratic regime"; that is, it must adhere to the professed values of the state. ${ }^{188}$ By following these ideals, a community achieves an "overlapping consensus" of reasonable political discourse, one that acknowledges a citizenry's respective comprehensive doctrines while approving of a collectively held notion of the political. ${ }^{189}$ In holding that citizens of a well-ordered constitutional regime ought to express only those propositions "others might endorse as consistent with their freedom and equality," Rawls thinks they perform a basic task of democracy, conducting themselves in accord with public reason. ${ }^{190}$

\footnotetext{
${ }^{186}$ John Rawls, “The Idea of Public Reason Revisited,” The University of Chicago Law Review 64, no. 3 (1997): 777.

${ }^{187}$ Political Liberalism, 453.

${ }^{188}$ Ibid., 454.

${ }^{189}$ Ibid., 10. Of course, Rawls is not attempting to eradicate comprehensive doctrines, only their appearance in public reason. On his view, a public conception of reason can be compatible with our devotional beliefs, fitting like a "module" into our private lives and enabling us to behave appropriately in the public sphere.

${ }^{190}$ Ibid., 218.
} 
On my view, Audi and Rawls' restriction of religion from public life — though not without its virtues and certainly preferable to the unsophisticated view I detailed above- - has many shortcomings. Though I am united with them in concluding that political pluralism is in dire need of rigorous philosophical adjudication (especially in regards to the multitudinous belief systems of citizens), and I concur that there must be some restriction of what kind of religious dialogue can be acceptable in political discourse, I find them to be overly restrictive of what religion has to offer political engagement. As an Arendtian, I am eager to secure political engagement from all citizens who wish to involve themselves in public deliberation; as such, I am wary that Audi and Rawls' positions especially hinder religious citizens from engaging in politics while still feeling they can live devout lives, which diminishes a community’s opportunity to construct the space of appearance and acquire political agency. Further, I think democracy is not only capable of honoring the divergent devotional particularities of its citizens, but that it is in need of these rival conceptions of the good, that our political discourse is actually improved by it.

Thus, in my judgment one can advance religious reasoning for a discrete law or policy even if she or he does not have a widely convincing rationale aligning with public reason. ${ }^{191}$ Hence, my position allows for a more reflexive form of political discourse, wherein secular and religious citizens can simultaneously influence one another in the spirit of what political theorist William Connolly has called "reflective engagement."192 Through this form of debate, we are given a more Arendtian view of religion in public life, one that attends more closely to plurality

\footnotetext{
${ }^{191}$ In many ways, I follow Christopher Eberle's argument for religion in political engagement. See his Religious Conviction in Liberal Politics (Cambridge, UK: Cambridge University, 2002).

${ }^{192}$ Which is to say, a form of public dialogue in which a citizenry's varying worldviews mutually inform and restrain one another. See William Connolly, Why I Am Not a Secularist (Minneapolis, MN: University of Minnesota, 1999$), 6$.
} 
and is more accepting of religion in exploring what it means to play the role of a citizen. I

elaborate on this type of politics now, beginning with my analysis of Habermas.

\section{Habermas}

Almost no philosopher has been as prolific or as impactful in the last half-century as Habermas; his writings having revolutionized social theory, legal thought, developmental psychology, and myriad other fields. ${ }^{193}$ My discussion of his work will therefore be severely restrained, revolving primarily around his recent works on religion in public life. With that, I provide just a brief overview of Habermas's work, especially looking to the ways his view of religion has transformed over time.

Although religion has been a near-constant object of attention throughout Habermas's career, the way it has featured in his corpus has changed dramatically. Earlier in his life, Habermas's relationship with the Frankfurt School significantly impacted his comprehension of religion. This influence is most apparent in his habilitation thesis, The Structural Transformation of the Public Sphere - a historical survey of the eighteenth-century development of the bourgeois class — in which he viewed religion in a predominantly Marxist vein. ${ }^{194}$ Following his estrangement from Adorno and Horkheimer, Habermas began to develop a sociological understanding of belief. At this stage of his career, he treated religion as an "archaic" mode of social integration, one that situates persons into distinct "lifeworlds" and serves as proof of an increasingly pluralized culture devoid of a "universal core." 195 Over time, however, Habermas

\footnotetext{
${ }^{193}$ According to Thomson Reuters, Habermas was the seventh most cited humanities scholar in 2007. See http://www.timeshighereducation.co.uk/405956.article for details.

${ }^{194}$ While in this period Habermas regarded religion mostly as an object of social control, he still thought it "retain[ed] an ineradicable philosophical" significance. See Jürgen Habermas, Religion and Rationality (Cambridge, MA: MIT Press, 2002), 7.

${ }^{195}$ Jürgen Habermas, The Theory of Communicative Action, Vol. I (Boston: Beacon, 1984), 138.
} 
has nuanced his view of religiosity, as his disillusionment with the standard secularization hypothesis has caused him to delve deeper into what faith can contribute to society.

Indeed, in the last two decades, Habermas has augmented his conception of religion, as he now sees it as a valid set of reasons for political and philosophical discourse. Calling his newfound position, "postmetaphysical," Habermas has recently asserted that contemporary philosophical thought should "refrain from making ontological pronouncements on the nature of being," subsequently avoiding the devaluation of everything whose truth value cannot be determined through "empirical observations." 196 With this view permeating his later philosophy, Habermas maintains a "soft-naturalistic" approach to the modern world, acknowledging the validity of scientific claims while affirming that they neither "exhaust what we can know about our shared social world" nor prohibit our interaction with alternative epistemologies. ${ }^{197}$ With this material, Habermas offers a favorable view of religion, claiming one cannot categorically affirm nor deny the "possible truth" content of devotional claims. ${ }^{198}$ For this reason, Audi and Rawls' arguments will be inadequate for him, his new perspective holding that religion contains constructive resources for cosmopolitan humanity.

Interestingly, Habermas has engaged with both Rawls and Audi on this issue, especially with the former. While Habermas commends Rawls for being one of the first theorists to seriously grapple with the inherent complications of religious pluralism, he regards the American philosopher as deeply misguided. ${ }^{199}$ According to Habermas, Rawls possesses an "overly

\footnotetext{
196 Jürgen Habermas, Between Naturalism and Religion (Malden, MA: Polity, 2006), 140-1. For Habermas these "non-rational" forms of discourse could include legal, moral and religious justifications.

${ }^{197}$ Melissa Yates, "Postmetaphysical thinking," in Jürgen Habermas: Key Concepts, ed. Barbara Fultner (Durham, UK: Acumen Publishing, 2011), 48.

${ }^{198}$ Ibid., 50.

${ }^{199}$ Between Naturalism and Religion, 147.
} 
narrow" view of religion in public affairs, unduly suppressing what religious citizens should be capable of advancing as public reasons and, consequently, making it increasingly difficult for them to pursue a pious and political life. ${ }^{200}$ Although Habermas acknowledges that Rawls similarly impinges on the comprehensive doctrines of nonreligious citizens, he perceives an asymmetrical burden assigned to devotional persons, and he thinks this excessively stringent elucidation of church-state separation misconstrues the neutrality principle's original purpose. Thus, with his notion of democracy Habermas seeks to enable citizens to exhibit their conceptual particularities, satisfying what he takes to be a more authentic commitment to constitutional neutrality in allowing religious devotees to politically express themselves in ways they can find fulfilling.

In a now famous essay, "Religion in the Public Sphere," Habermas commences his argument with an appeal to constitutionalism, stating that allowing religious reasons to enter public debate adheres more closely to liberal democracy's principle of neutrality. On his view, this is particularly true of an American democratic framework, which has codified its objection to anti-religious "laicism" since Virginia's Bill of Rights in 1776, ensuring a citizenry's “positive liberty" to practice their respective religions. ${ }^{201}$ According to Habermas, the Constitution mandates this strict impartiality toward religion, which should accordingly grant religious persons in civil society the opportunity to advance their reasons under the aegis of a common obligation to the state. ${ }^{202}$ Therefore for Habermas it is simply implausible to expect liberal

\footnotetext{
${ }^{200}$ Ibid., 123. While this is not Rawls' intention, Habermas perceptively argues that religious devotees may be forced to choose between using proper political reasons and upholding their religious values.

${ }^{201}$ Ibid., 118. According to Habermas, religious tolerance can only be secured within a democratic polity. In this way, he echoes Arendt's contentions that a people's rights are derived from their status as a citizen. See ibid., 254.

${ }^{202}$ Georgia Warnke, "Communicative rationality and cultural values" in The Cambridge Companion to Habermas, ed. Stephen K. White (Cambridge, UK: Cambridge University, 1995), 123.
} 
citizens to exclusively tender political positions "independently of their religious convictions or worldviews," a standard that places an "undue burden" on those who lack access to an auxiliary worldview. ${ }^{203}$

Civil society is indeed the operative term here, as Habermas repeatedly writes that religion must be met with an appropriate amount of restraint in official governmental procedure. Although he is willing to concede that devotional argumentation is valid in the "informal public sphere," he argues "only secular reasons" can be of consequence beyond the "institutional threshold" of politico-legal bodies, ${ }^{204}$ maintaining that "binding political decisions" must be adjudicated and legitimated in a nonreligious capacity. ${ }^{205}$ Accordingly, Habermas advocates what he identifies as a "soft burden" on democratically engaged religious individuals, claiming that in their deliberation with political organizations they must at minimum attempt to translate their rationale into secular parlance. ${ }^{206}$ If religious devotees follow this logic, Habermas thinks they subsequently contribute to crafting a more inclusive public sphere overall, with both religious and irreligious citizens acknowledging the multiplicity of doctrines within the "shared ethos" of democracy. Moreover, Habermas does not judge that religious citizens should be exclusively burdened in public discourse, and he argues that secularists must shoulder some of this responsibility as well.

In an attempt to construct this more tolerant public sphere, Habermas contends that secular citizens should face corresponding encumbrances in their public discourse. Specifically,

\footnotetext{
${ }^{203}$ Between Naturalism and Religion, 128.

${ }^{204}$ Ibid., 130. Habermas has in mind courts and administrative officials, but also other political organizations that can compel citizens through legal force.

${ }^{205}$ Power of Religion, 64. Interestingly, here Habermas provides a variation of the "Entanglement Prong," a legal principle stipulating that a "statute must not result in an excessive government entanglement with religious affairs." For more on how this case affects religious liberty, see https://supreme.justia.com/cases/federal/us/403/602/case.html.

${ }^{206}$ Between Naturalism and Religion, 136-7.
} 
he believes secular persons should feel obligated to engage with and translate faith-based reasons into nonreligious terms, assisting these otherwise inappropriate propositions so they can be introduced into formal political settings. ${ }^{207}$ In some ways for Habermas, this follows from ascribing to a postmetaphysical worldview; throughout this more recent work he maintains that civic responsibility entails being "epistemically attuned" to the various comprehensive doctrines citizens care for. ${ }^{208}$ While Habermas does not want dialogue of this kind to be a legally imposed, he thinks taking up these complementary burdens will result in an improved conception of citizenship, allowing "monolingual" interlocutors and their more-broadly reasoning compatriots to attend to and potentially learn from each other's respective lifeworlds. ${ }^{209}$ In mutually fulfilling these democratic stipulations, Habermas aspires to construct a more permissive liberal democracy, one in which citizens encourage the inclusion of religious reasons rather than merely tolerate them. However, Habermas is not appealing solely to liberal fairness here, as faith-based reasoning also has instrumental value for democracy.

Because postmetaphysical thought refrains from trivializing non-secular modes of thinking from society, Habermas holds that religion can also improve our political discourse, offering epistemic resources to ameliorate issues other conceptual apparatuses cannot. ${ }^{210}$ On his view, religion (especially Judeo-Christian religion) has played an indispensable role in shaping Western political civilization, "articulat[ing] moral intuitions" that—while nonetheless necessitating translation in an official locality — has contributed vital ethical opinions to our

\footnotetext{
${ }^{207}$ Ibid., 131-2.

${ }^{208}$ Ibid., 139, original emphasis. Conversely, people of faith must be aware that they inhabit a secular state.

${ }^{209}$ Power of Religion, 26.

${ }^{210}$ In one sense, this tenet is a result of postmetaphysical thought. As Habermas contends, "as long as religion can still say something that philosophy cannot, then philosophy...will not be able either to replace or to repress religion." See Religion and Rationality, 26.
} 
modern political imaginary. ${ }^{211}$ For Habermas, this paradigm finds an exemplar in Martin Luther King, Jr., who despite operating from an unabashedly religious standpoint remained politically effective in propounding lucid and existentially compelling postulations for religious and irreligious citizens alike. ${ }^{212}$ In short, Habermas thinks postmetaphysical society can learn from religious traditions and figures like King while remaining agnostic about their faith claims, tapping into the "semantic potentials" they offer for improving the public sphere and wider society.

Through Habermas, we obtain a more tolerant model of religion in the public sphere, as he convincingly argues that democracy "must be open to all," in many ways concurring with the idea that plurality necessitates "reflexive" engagement with an abundance of one's fellow citizens. $^{213}$ Thus, Habermas's conception of religious pluralism is congruent with an Arendtian understanding of religion in the public sphere. Still, Habermas is not faultless.

Although I am taken with Habermas's lenient view of religion in public deliberation — not to mention his compelling refutation of Rawls - some aspects of his work are especially problematic. Even if one can look past his instrumentalization of religion, the underlying assumption of the institutional proviso raises some concerns. In essence, I am circumspect that Habermas's addendum to the Rawlsian proviso will be effective for improving our public discourse, and I wonder whether "moving [the] proviso up one step" to officials and lawmakers actually resolves our socio-political dilemma. ${ }^{214}$ While in questioning this tenet I am not

\footnotetext{
${ }^{211}$ According to Habermas, Hegel's notion that "the major world religions belong to the history of reason itself" underlies this argument. See Ibid., 6.

${ }^{212}$ Power of Religion, 65. While this view is hardly exclusive to Habermas, it plays into his framework well.

${ }^{213}$ Ibid., 128. As Habermas argues (perhaps too optimistically), translation of religious reasons by secular individuals can provide the opportunity for all citizens to attend more carefully to the moral injunctions of religious teachings.

${ }^{214}$ Cristina Lafont, "Religion in the Public Sphere: What are the Obligations of Democratic Citizenship?" in Habermas and Religion, eds. Calhoun, Mendieta, VanAntwerpen (Malden, MA: Polity Press, 2013), 237.
} 
advocating that judges or politicians should be capable of basing their judgments on faith claims, on my view Habermas's schema continues to provide an expedient method for relegating religious premises to the political periphery. In doing so, he renders many devotional arguments and the concerns of the citizens who advance them illegitimate, alienating them from the political process when their contributions may matter most.

Further, Habermas's overall political project is unduly concerned with "ideal speech situations," excessively fixated on arriving at a consensus between religious and irreligious citizens. ${ }^{215}$ Though agreement is undoubtedly an important aspect of any functional body politic, the Arendtian conception of plurality I have outlined in this thesis is cognizant of democracy's "fiercely agonal spirit," recognizing that at times unrelentingly pressing for solidarity can be counterproductive to the construction of robust political bonds. ${ }^{216}$ In one respect, Habermas seems inattentive to Arendt's understanding of the inherent "haphazardness" of politics, of its indeterminate outcomes regardless of the regulations one places on speech and action. ${ }^{217}$ Thus, while Habermas is helpful in some ways, he diverges from my Arendtian reading of political engagement. Therefore, I turn to Jeffrey Stout, whose pragmatic democratic framework further elucidates how religion can be acceptable in public life.

\section{Stout}

Although not personally religious, ethicist and scholar of religion Jeffrey Stout believes faith-based justifications have something useful to contribute to liberal democracy, that they are an admissible form of public rationale that unveil new frames of reference for political

\footnotetext{
${ }^{215}$ Here I take after Danielle Allen, who offers a lengthy and sophisticated critique of Habermas in Talking to Strangers: anxieties of citizenship since Brown v. Board of Education (Chicago: University of Chicago, 2004).

${ }^{216}$ For Arendt, the essential elements of politics do not lie in legislation. See The Human Condition, 41, 194.

${ }^{217}$ Ibid., 220.
} 
engagement. In his Democracy and Tradition, Stout provides a more Arendtian form of political discourse, constructing a method for including religious individuals in the public sphere.

In the most general terms, Stout's goal in Democracy and Tradition is to establish a proper appreciation of democracy, which in his view is principally the activity of "giving and asking for ethical reasons" from one's fellow citizens, the collective act of incessantly renegotiating the way members of a community live with one another. ${ }^{218}$ In distinction to Audi and Rawls, the pragmatist Stout thinks it is implausible to expect religious devotees to "bracket" their "deepest commitments" in public deliberation, and he is adamant that citizens of democracies should "feel free" to "express whatever premises" perform as justifications for their arguments. ${ }^{219}$ Accordingly, Stout is suspicious of the idea that democracy is best served by holding to a uniform conception of public reason, or that cultural "idioms" necessarily endanger the legitimacy of political debate. ${ }^{220}$ Taking a somewhat idiosyncratic approach to political theory, Stout lends a glimpse of democracy as a tradition, showing in greater detail how religious citizens can engage liberal politics. ${ }^{221}$ Like Habermas, Stout commences his argument with a critique of Rawls.

Beginning his analysis with a poignant question, Stout asks: "What role, if any, should religious premises play in the thought process citizens engage in when they make and defend

\footnotetext{
${ }^{218}$ Jeffrey Stout, Democracy and Tradition (Princeton, NJ: Princeton University, 2004), 6. In this way, Stout diverges from Habermas, as the former is more curious about the tenor of our politics than the implications of the Constitution. For a text that similarly contends with the issues inherent in deciding how a collective ought to negotiate their living with one another, see Hanna Pitkin, Wittgenstein and Justice: On the Significance of Ludwig Wittgenstein for Social and Political Thought. (Berkeley, CA: University of California, 1972).

${ }^{219}$ Democracy and Tradition, 10.

${ }^{220}$ Ibid., 11.

${ }^{221}$ Stout also shares my ambivalence of Habermasian ideal speech acts, regarding them as a novel form of "moral Esperanto"; that is, a moral theory that unrealistically aims to amalgamate individuals into a common ethical language. See Stout's Ethics After Babel: The Language of Moral and Their Discontents (Boston: Beacon, 1988$), 166$.
} 
political decisions?"222 Initially agreeing with Rawls, Stout concurs that "proper treatment" of one's fellow citizens in advocating specific policies requires honestly attempting to justify their reasoning to their deliberative interlocutors. However, from here Stout finds Rawls' "contractarian" approach overly restrictive, particularly with the assertion that citizens are "reasonable" only if they "govern their conduct" in accord with a "freestanding conception of justice. ${ }^{223}$

To be sure, what Rawls counts as public reason strikes Stout as confining, unnecessarily limiting what kinds of practices can occur in democracy while diminishing potentially advantageous moral opinions. ${ }^{224}$ On Stout's view, not only does strict adherence to this social contract theory effectively exclude scores of religious devotees from public dialogue, but he maintains that political reasonability—or, being a "socially cooperative" citizen—is not overridden if one employs religious arguments. In addition, Stout is especially critical of the Rawlsian proviso, particularly in its response to figures like Abraham Lincoln or Martin Luther King. While one could scarcely doubt that these individuals are exemplars of the democratic tradition, helping navigate America through debatably its two most existentially threatening tribulations, Rawls himself asserts that in certain cases they may not have satisfied the proviso, their quasi-religious public rhetoric potentially counting only for "private speech." ${ }^{225}$ If neither the "Second Inaugural" nor "Letter from Birmingham Jail" can count as public reason, then Rawls' contractarianism will remain wholly implausible for Stout, as he will ultimately argue

\footnotetext{
${ }^{222}$ Democracy and Tradition, 63.

${ }^{223}$ Ibid., 67.

${ }^{224}$ Ibid., 66. Stout is partially wary of Rawls' liberalism because he thinks it can only create "thin" virtues, which he thinks persuades some religious individuals to alienate themselves from political discourse into what Stout calls "enclave societies." See ibid., 114-5.

${ }^{225}$ Ibid., 69.
} 
that interlocutors can be considered politically reasonable if they are "epistemically entitled" to their beliefs and conduct themselves according to their "epistemic responsibility." ${ }^{226}$ Hence, Stout looks favorably on religion in the public sphere, and he recognizes that religious devotees offer seldom-heard resources to democracy.

Essentially, Stout regards faith-based arguments as valid in political deliberation, reframing the question of religion in the public sphere by opening up the category of public reason. In addition, he thinks a democratic polity is strengthened by the inclusion of disparate viewpoints, a contention he holds both in his theoretical ruminations on the nature of democracy as well as his ethnographic analyses of particular communities.

Continuing to press Rawls, Stout wonders if the author of Political Liberalism finds religious premises problematic because it could be considered disrespectful to reason from an esoteric point of view when one's dialogue partner operates from a neutral perspective. This certainly could be the case; after all, current events are replete with examples of religious citizens whose public interaction would at best be described as uncivil. ${ }^{227}$ However, Stout is not convinced that arguing from a specialized conceptual framework is necessarily discourteous; on the contrary, he claims nothing could be more deferential in political debate than honestly providing one's actual reasons to interlocutors, beckoning them into "Socratic conversation" in a sincere effort to persuade them while avoiding manipulation. ${ }^{228}$ Labelling this method of public

\footnotetext{
${ }^{226}$ Ibid., 71. Though he does not mention him here, Stout's conception of religiosity and political responsibility as intertwined seems to be a refutation of Audi.

${ }^{227}$ I have particularly in mind a group like the Westboro Baptist Church, although a group need not be as contemptuous as they are to be disrespectful to their interlocutors.

${ }^{228}$ Ibid., 72. As I read Stout, concealing one's actual reasons for supporting a law or policy could be construed as a kind manipulation of one's fellow citizens, thereby disrespecting them.
} 
deliberation "immanent criticism," 229 Stout thinks offering religiously tinged arguments to distinctly reasoning persons can be a paramount form of regard for that other citizen, acknowledging their equality and distinction while not sacrificing one's own deeply held beliefs.

Thus, Stout thinks it is more sensible to treat public reason as a "vague ideal," advancing particular arguments to particular individuals when prudent and altering one's deliberative strategies depending on circumstances. ${ }^{230}$ This schema of public discourse is especially appealing for Stout given his conception of the way a society determines its norms. Arguing alongside Hegel and fellow pragmatist Brandom, Stout contends that in the democratic "game" of giving and asking for reasons, norms - like the rules of any practice - are subject to dialectical revision, with "practice-transforming performances" fundamentally changing that social sphere. ${ }^{231}$ Therefore, reasons are better viewed as contingent on the "dialectical location" from which an individual emerges, making a competent political interlocutor anyone who "participates responsibly in the process of discursive exchange," anyone whose deliberative contribution has the potential to help create a "more perfect union." 232 Through this lens, religion can (when used responsibly) beneficially sustain the democratic project, employing respect, immanent criticism, and the virtues of civil dialogue to refine our public deliberation. ${ }^{233}$

\footnotetext{
${ }^{229}$ Indeed, immanent criticism is something of a key term for Stout, by which he means a manner of intellectual exchange in which one genuinely engages with the views and arguments of her or his interlocutors, showing them due regard by intently listening to them while continuing their attempts at persuasion. Resembling a conversation in and of itself, Stout thinks this argumentative strategy avoids alienating interlocutors and draws them deeper into dialogue with other forms of reasoning. Put another way, immanent criticism seeks to understand an interlocutor before passing judgment on their views. It stands to note that part two of Democracy and Tradition follows the rubric laid down by immanent criticism, as Stout's assessment of thinkers like Hauerwas and Milbank comes only after engaged exegesis.

${ }^{230}$ Ibid., 75.

${ }^{231}$ Ibid., 79.

${ }^{232}$ Ibid., 82.

${ }^{233}$ Ibid., 85.
} 
While Stout has sufficiently problematized cardinal axioms of Rawlsian contractarianism, the question of whether religion is ever politically prudent remains; whether, that is, religious premises necessarily suspend public discourse. Although Stout admits faith-claims ${ }^{234}$ can be problematic for political deliberation, asserting that all religious propositions take the form of faith-claims disregards the countless devotees willing to debate the merits of their doctrines with those of dissimilar belief structures. Further, Stout avers, faith-based claims are not exclusive to religious individuals. On the contrary, everyone that participates in political debate in various capacities must periodically defend opinions they cannot completely justify, and even secular individuals must now and then stand up on issues for which they have no certainty. ${ }^{235}$

Herein lies the key to understanding Stout's conception of democracy, and subsequently why_-from an Arendtian point of view_religious argumentation can make a positive contribution to the vitality of political discourse. Because we are entitled to affirm and politically discuss at least some non-verifiable tenets (religious and nonreligious alike) Stout rightly judges that excluding only those principles that are religious in origin is both hypocritical and unfair. ${ }^{236}$ Rather than prohibiting citizens from using their respective "final vocabularies"237 in the public sphere, Stout alleges that a better way to foment passionate political debate is to sincerely consider the ideals differently reasoning persons contribute to a particular discourse. By beckoning citizens to provide their genuine motivations to one another, Stout thinks democracy

\footnotetext{
${ }^{234}$ Stout defines faith-claims as assertions that make "a cognitive commitment without claiming entitlement for that commitment." See ibid., 86.

${ }^{235}$ Ibid., 87. In this respect, Stout thinks religious and secular political reasons are epistemically equivalent.

${ }^{236}$ Ibid., 88.

${ }^{237}$ For Rorty, a "final vocabulary" is the set of ingrained axioms one categorically regards as true, those claims that cannot be reduced to any further underlying principles.
} 
maintains its "conversational" ethos, relying on a diversified set of political sensibilities to better adjudicate how to live with one another. ${ }^{238}$

Undeniably, there will be varying levels of success in this kind of endeavor, and at times religious arguments may pose difficulties to our public deliberation. Regardless, Stout concludes that we must look past the apocalypticism and negativity that so often accompanies our modern political experience, that we must continue to be active members of a democratic society despite the insoluble deficiencies of political life. ${ }^{239}$ With Stout's ultimate goal being to generate a "community of reason-givers," it is indeed difficult for him to submit that alienating religious interlocutors from our public dialogue is the right answer, as the essential democratic practices of "ethical deliberation and political debate" above all require the inclusion of citizens who will care for their governmental body. ${ }^{240}$ But still, one might be curious to know how Stout would implement these ideals into active political engagement.

In his Blessed Are the Organized, Stout contextualizes the arguments made in Democracy and Tradition, illuminating how some citizens — specifically, community organizers - epitomize his method of public deliberation, not merely acknowledging religion as a valid set of public reasons but regarding their devotional beliefs as integral to achieving specific political goals. In some ways resembling this thesis, Stout begins by claiming that there are legitimate problems in our modern political discourse, and that we may need to seek unconventional resources to reinvigorate our public dialogue. For Stout, the solution to this dilemma will at least partially come from grassroots democracy, from the "strengthened, extended, and multiplied" networks of

\footnotetext{
${ }^{238}$ Ibid., 89-90.

${ }^{239}$ Ibid., 289.

${ }^{240}$ Ibid., 293.
} 
citizens who cooperate to bring about various kinds of change. ${ }^{241}$ Within this activist mode, religion and politics are not necessarily bifurcated, for grassroots organizers recognize that faith is often ineluctably tied to who a citizen is and that one's beliefs can inspire their interactions with their government. ${ }^{242}$ Providing a gripping ethnographic analysis of groups like Jeremiah and One LA (affiliates of the Industrial Areas Foundation and intellectual descendants of Saul Alinsky), Stout confirms that for some, "looking after the welfare of your country" demands faith. $^{243}$

For institutions like Jeremiah, religion is not just something organizers maintain in their private lives, nor does it simply inform how they fulfill their official duties as political organizers. On the contrary, religious organizers maintain that their faith compels them to engage in political movements, that their "belief" in what community organizing can accomplish is itself rooted in their religious devotion. ${ }^{244}$ However, the relationship between religion and community activism is not limited to one's profession of faith. Rather, IAF affiliates frequently interweave religion into their political activities, utilizing prayer, spiritual idioms, and other faith-based discourses to procure engagement from previously untapped arenas. ${ }^{245}$ While one might expect that publicly employing religious locutions or practices would alienate some or perhaps most nonreligious interlocutors, grassroots democracy's commitment to the "culture of mutual recognition" requires listening to the genuine reasons citizens propound in dialogue, as well as

\footnotetext{
${ }^{241}$ Jeffrey Stout, Blessed Are the Organized: Grassroots Democracy in America (Princeton, NJ: Princeton University, 2010), xiv.

${ }^{242}$ Ibid., xvii.

${ }^{243}$ Ibid., 21. Of course, grassroots democracy is not limited to religious organizations. However, Stout and several of his dialogue partners make it clear that many organizing movements would be impotent without religious devotees.

244 Ibid., 4.

${ }^{245}$ As Stout notes on ibid., 193, community organizers occasionally incorporate quasi-sacramental rituals into political engagement, impacting citizens who never would have considered engaging with politics otherwise and expanding a group's purview. For more on religious practice in community organizing, see Luke Bretherton, Resurrecting Democracy: Faith, Citizenship, and the Politics of Common Life (Cambridge, UK: Cambridge University, 2015).
} 
holding them accountable to those convictions. ${ }^{246}$ Moreover, religious leaders often become authority figures in organizing groups. Throughout Blessed, Stout shows how Jeremiah and other institutions rely on priests and deacons to "knit" communities together and galvanize engagement, applying a faith-based perspective to numerous issues. ${ }^{247}$

Most basically, Blessed illustrates that voicing religious reasons in the public sphere is not incompatible with caring for the "common good"; after all, religious citizens are still citizens, and are therefore well-suited for tending to the matters of their local as well as national communities. ${ }^{248}$ While Stout is correct to indicate that religious motivation in community organizing often stems from a feeling of responsibility, he also perceptively notes that arguing from a religious standpoint if one possesses it represents a more honest method of participation in the American democratic process. Such a method fosters community among diverse groups of people, empowering those previously unaware of the ways faith can impact the world ${ }^{249}$ and creating something that Arendt might identify as the space of appearance. In one sense providing an extensive example of immanent criticism, Blessed shows that using religion in public discourse is not exclusively reserved for figures like Lincoln and King, but is the personal duty of every religious citizen.

Indeed like Arendt, Stout convincingly argues throughout his corpus that a healthy democracy necessitates input from a wide variety of conceptual sources, of which religion can

\footnotetext{
${ }^{246}$ Blessed Are the Organized, 63.

${ }^{247}$ Ibid., 169.

${ }^{248}$ Ibid., 197. Although Stout grapples primarily with Christianity in this text, he is aware that different books could be written for other religious traditions and democracy.

${ }^{249}$ Ibid., 235. One notable example of this phenomenon from the text comes from a meeting in which a number of Christians were hesitant about using their religion in political engagement, or indeed engaging in politics at all. Amidst a relatively heated discussion in which some participants asked "Why can't we talk about Jesus?," a member of One LA enthusiastically retorted "But we can talk about Jesus!" See ibid., 209.
} 
certainly be one. On the most rudimentary level, if a group of citizens can engage the public sphere responsibly and have mutual recognition for their interlocutors, he thinks they can employ their genuine reasons to advocate particular laws or policies, appealing to one another in a way that recognizes their shared commitment to a community. ${ }^{250}$ By embracing one's own beliefs modestly and reserving generosity for others, Stout outlines a more Arendtian public sphere, one chiefly concerned with upbuilding plurality and continuing the democratic conversation.

\section{Arendt Reconsidered}

At this point it is necessary to re-incorporate Arendt into our discussion, to elaborate on the ways Habermas and Stout have illuminated new facets of my Arendtian ideal of political engagement. In essence, this chapter has considered the question of proper citizenship, specifically ruminating on how those with seemingly improper political reasoning can introduce their arguments into human affairs and participate in democratic discourse. Although Arendt rarely discusses the import of religion in political engagement, ${ }^{251}$ my analyses of Habermas and Stout have nonetheless suggested that an Arendtian conception of plurality is amenable to the inclusion of varying types of expressions in democratic deliberation. Through these writers, I have insisted that liberal democracies — while purportedly irreligious in both legal and institutional organization - ought not be absolutely secularist, that they should not be completely averse to faith-based modes of thought in political engagement.

\footnotetext{
${ }^{250}$ Democracy and Tradition, 304. Stout's argument here resembles William Connolly's, who has contended that in political discourse one ought not seek to "replace one scheme of universalization with another," but should instead "place a contending perspective more actively on the field of contemporary debate," effectively perpetuating the democratic conversation ad infinitum. See William Connolly, The Augustinian Imperative: A Reflection on the Politics of Morality (Oxford, UK: Rowman and Littlefield, 1993), xxi.

${ }^{251}$ While she devotes little attention to religion in politics, Arendt does discuss secularization and Augustine's role in reviving the concern for the political in Christianity. Although this is ancillary to my discussion, it lends additional detail to her thought. See Hannah Arendt, The Promise of Politics (New York: Random House, 2005), $135-141$.
} 
This chapter has demonstrated that dialogue with religious sources is at times indispensable for public life, as some issues lack the existential thrust faith-based reasoning provides. This has a significant bearing on Arendt's thought. One of the consequences of plurality for Arendt is that the citizens who constitute the public sphere must serve as "bodyguards" for one another, safeguarding each other's ability to disclose their identities to their fellow citizens. Indeed, Arendt views plurality as an ineluctable component of human affairs, a principle that is dependent upon the equality and distinction of those who engage in political action. However, in her opinion, equality is not interchangeable with "sameness," nor is distinction mere "alteritas." ${ }^{252}$ Rather, for Arendt equality and distinction are indicative of a citizen's ability to reveal her unique personhood in political discourse, the capacity to distinguish herself from her compatriots and become immersed in webs of relationships. Exhibiting some similarities to Habermas, Arendt places a supreme importance on the ability to display one's discursively formed self in the public sphere, relying on acting and speaking with one's fellow interlocutors to craft a more enthusiastic political exchange.

Therefore, despite her espousal of constitutionalism and liberal democracy, Arendt does not tread down a Rawlsian path, as she acknowledges the substantive contributions non-freestanding doctrines can make in the public sphere. Indeed, she anticipates that various argumentative strategies will enter into our public dialogue, and she is receptive to the idea that these types of reasoning can be politically valid when citizens engage appropriately. ${ }^{253}$ In a sense then, Arendt conceives of the operations driving public deliberation as akin to Stout's democratic

\footnotetext{
${ }^{252}$ Arendt identifies alteritas as a tenet of medieval philosophy, defining it as the state of intrinsically possessing difference as a result of being. See The Human Condition, 176.

${ }^{253}$ In one of the few passages where she explicitly discusses the intersection of religion and politics, Arendt claims that the advent of "secularization" signifies little beyond the legislative separation of church and state, implying that democratic discourse need not exhaustively divorce politics from religion. See ibid., 253.
} 
conversation, in which the politically engaged acknowledge the distinct persons they interact with, each of them recognizing that they share a common goal of seeking to improve their democratic union.

In addition to arguing that plurality allows for a multiplicity of voices to enter the public sphere, one of the underlying themes in this thesis has been to illuminate the agonism of Arendt's political theory. In her formulation of politics, ideological differences between citizens ought not prevent them from interacting with one another. Diverging from the Habermasian emphasis on consensus, Arendt values the "agonal spirit" of democracy, maintaining that the "passionate drive to show one's self" is the premier political act undergirding our shared democratic "conversation." 254 Following this archetype of political engagement, Arendt would clearly be at odds with a strict interpretation of church-state separation in the vein of Audi or Rawls, and she would not consider a diverse set of "public languages" as necessarily reductive of the collective act of giving and asking for reasons. Thus, while political institutions are undoubtedly consequential features of the political process, Arendt is ultimately more concerned with the continued interaction of citizens and the subsequent upbuilding of our democracy. ${ }^{255}$

As this brief overview has made clear, Arendt envisions democracy as a domain in which citizens chiefly seek to acknowledge the distinct persons speaking and acting with one another in the public sphere. Given this open conception of political engagement, she would find it wholly unacceptable to preclude religious voices from public deliberation, as it is imperative on her view to allow for as many people in our political discourse as action allows. Upon doing so, a

\footnotetext{
${ }^{254}$ Ibid., 194.

${ }^{255}$ As Arendt scholar Dana Villa convincingly argues in Public Freedom, Arendt's reverence for the founding of a state signifies that her political framework relies on more than supporting laws or institutions, as her focus remained with "creating and sustaining a 'shared feeling of the world', a sensus communis." See page 106.
} 
community reifies a more vibrant polis — creating something more closely resembling the space of appearance through their collective power - wherein each politically distinct voice is "recognizable as such by all others.",256

Although Habermas, Stout, and Arendt differ on minute points, their collective understanding of political engagement as necessitating the incorporation of diverse conceptual outlooks helpfully shows how a multitude of voices can constructively contribute to public deliberation, simultaneously aiding this thesis in its general objective. By allowing religious citizens to play a more active democratic role in their capacity as persons of faith, the American citizenry as a whole obtains newfound resources to reinvigorate our dialogue on protracted issues. In doing so, we also invite religious devotees - particularly those previously isolated from democratic discourse - to use their preferred rationale in the public sphere, thereby allowing more individuals to engage with their political institutions. While this inclusivity will undoubtedly pose its own political difficulties, taking the claims of religious citizens into account contributes to a more spirited public discourse overall. Counteracting and potentially overcoming our current governmental dysfunctions will undoubtedly require such a vibrant public sphere, as a citizenry must draw from a variety of communities to make change.

In this chapter, I have demonstrated that religion can make a significant contribution to public life and that an Arendtian view of engagement regards religious argumentation as politically valid. Although Arendt rarely discusses religion explicitly, my two primary interlocutors illuminated one repercussion of plurality, as they provided a vision of a more flexible public discourse in a way that diverges from the strict Audi/Rawls' interpretation of

\footnotetext{
${ }^{256}$ Ibid., 20-1.
} 
liberal democracy. Through Jürgen Habermas I showed that permitting religion in political discourse satisfies the liberal democratic notion of neutrality, that a truly impartial democracy permits religious citizens to engage the public sphere with their most deeply held convictions. In addition, Habermas argues religion has a function in democratic societies, disclosing supplementary moral intuitions secular individuals may not have recourse to otherwise. Offering a forceful critique of the Rawlsian position, Habermas persuasively reasons that an uncompromising conception of church-state separation runs counter to the development of a constructive democratic state.

However, Habermas is insufficient to counteract liberal democracy's woes, his institutional proviso presenting an analogous problem to Rawls. Seeking resources elsewhere, I turned to Jeffrey Stout, whose understanding of democracy allows for heterogeneous epistemological vantage points to engage in democratic conversation provided they are introduced responsibly. Further, Stout established that political engagement can be strengthened with the inclusion of religious voices, in some ways echoing my analysis of plurality. Through these thinkers, I outlined a more Arendtian notion of public deliberation, one that seeks to dialogue with a multiplicity of interlocutors to bring an engaged polis more closely into view. ${ }^{257}$ Having given a thorough yet certainly not exhaustive elaboration of Arendt's conception of politics, it has been my aim throughout this thesis to improve our public discourse, to provide us with further resources for action. Although I realize one work is hardly sufficient to vivify American public life, I submit this in the hopes that it has put us on the right path.

\footnotetext{
${ }^{257}$ While my focus has remained primarily with the ways religion ought to be included in public discourse, this chapter has shown that plurality could implicate a wide variety of other views as well.
} 


\section{Afterword}

One hardly understands a work of this kind before writing it, and one of the chief lessons I have learned in composing this thesis is that every academic effort feels somewhat unfinished upon completion. Nonetheless, beginnings imply endings, and I offer this afterword not to clarify the arguments I have made but to report on what I believe I have done. Before offering these final reflections, however, I will summarize the chief aims of each chapter. While I have undoubtedly left many stones unturned, I submit this work in the hopes that it provides a more Arendtian view of political engagement.

In this thesis, I have elucidated Hannah Arendt's political theory, looking to her thought as a way to counteract and potentially overturn the dysfunctions of our contemporary political culture. In some ways emulating Arendt herself, I have attempted to critique both specific issues in American society as well as how these problems contribute to the more pervasive dilemma of political complacency. With this framework in mind, in my first chapter I introduced Arendt, expounding on her vita activa and explaining what resources she provides for a community seeking to reinvigorate its public life. In this opening chapter, I argued that if we are to repair some of the political difficulties facing modern citizens, we will need to adopt something resembling her tenet of action.

However, I also noted that Arendt's writings-illuminating though they are-occasionally bewilder readers, her failure to contextualize some of her operative terms detracting from the overall usefulness of her theory. Therefore, in chapter two I furthered my analysis of Arendt, using post-structuralism to uncover the ways plurality is concomitant with a kind of political pluralism. Ultimately I revealed that for Arendt, it is imperative for citizens to 
recognize the innumerable perspectives of those who inhabit the public sphere, and to draw on those distinctive wills and intentions to strengthen political discourse.

I then entered Arendt into a contemporary political debate, using her work as a way to scrutinize one impediment to public deliberation. More specifically, in chapter three I asserted that Arendt's concept of plurality would seek to include religious argumentation in political discourse. By upholding the virtues of liberal-constitutional democracy while not allowing it to run roughshod over the particularity of citizens, I presented what I take to be a more Arendtian view of public life. Throughout all these chapters, my overall objective has been to contend with how to establish a more robust political discourse from an Arendtian perspective, and while I have barely made a dent in the conversation, I think I have provided a fresh outlook on some of these questions.

Writing this thesis in a Religious Studies department, the question "Why Arendt?" has often been lobbed in my direction. In response to these queries, I have attempted to use her work in two ways. Firstly, I have found her concepts of power and plurality incredibly useful for attaining a better sense of our communal being-in-the-world, yielding valuable resources for religious and irreligious citizens alike. In addition, I think her attention to tangible, on the ground governmental phenomena while discussing abstract philosophical thought is a necessary approach for political theory (or political theology for that matter) to take, especially in our efforts to generate a more vibrant civic life today. Imitating this method, my involvement with politics in the city of Charlottesville has progressed alongside this thesis, illuminating to me firsthand how power manifests itself within plurality. To claim it has been a tumultuous year in Charlottesville would be a deplorably mild understatement, but in watching the citizens of this 
community respond to the problems they face, I have seen what resembles Arendtian-style action, and I have witnessed citizens benefit from their use of it. From public protests to city council meetings to open dialogues, partaking in Charlottesville politics has transformed this thesis, providing me with something of a testing ground for Arendt's thought.

On the most fundamental level, my goal here has been to aid my fellow citizens - be they Charlottesvillians, Virginians, or Americans_-in facing the political dilemmas of our day. While our troubles may pale in comparison to some of the tribulations Arendt faced, two things are as true for us as they were for her. As we undeniably know, there are legitimate problems in modern political discourse, a predicament that at least partially stems from the inability of our citizens or lawmakers to constructively contribute to public dialogue. However, also true is the fact that Arendt knew the best way for citizens to overcome these dilemmas was to engage with the policies, institutions, and officials themselves, relying on the power that results from plurality to overturn the detrimental aspects of politics. Put differently, for Arendt the best way to counteract the difficulties of political life is to become a more active citizenry.

On my view, Arendt's desire for more active participation in the public sphere is reflected in her commendation of the town council system. Throughout her work, Arendt lauds this form of political discourse, deeming its face-to-face communication and recognition of individuality "public happiness." ${ }^{258}$ Having attended many of these intimate political proceedings here in Charlottesville, I have gained a clearer comprehension of Arendt's meaning. Differing dramatically from the City Council gatherings I described in the foreword of this thesis, the town meetings I visited almost strove for informality. At these events, citizens freely voiced their

${ }^{258}$ On Revolution, 165. 
concerns for their community, using any kind of parlance-religious, academic, blue-collar, etc. - the occasion seemed to call for. Moreover, participants openly argued with one another; sometimes about important legal distinctions in a particular city ordinance, other times about the safety of their community or damage done to their drinking water by industrial technology. Although the conversation struggled to remain congenial at times, it was clear that this was a more honest public discourse, and meetings always seemed to conclude with a palpable sense that the community as a whole was better served through candor than bitten tongues. Though it remains unclear how one could extrapolate the communicative styles of these close-knit collectives to the national or even regional stage, maintaining their interactive posture will be necessary to ameliorate public deliberation.

Realistically, our institutions are far too vast and complicated to reasonably expect this stereotypically New England-style of governance to thoroughly repair our political dialogue. Still, the town meetings are a living testament to the "imperative of citizenship," evidence that caring citizens can safeguard the welfare of their community and acknowledge that their polity's health is dependent on them. ${ }^{259}$ Arendt would undoubtedly affirm this sentiment and would add that this imperative requires that persons not cloister themselves into groups oriented around particular political ideologies or class structures. Rather, for Arendt, the endeavor of actively being involved in our community is best accomplished by familiarizing ourselves with as many individuals perspectives as plurality will allow, each disclosure of identity recognizing another's equality, distinction, and common obligation to the polis.

\footnotetext{
${ }^{259}$ I take the quoted phrase from President Obama's speech given in Selma, AL on the 50th anniversary of the "Bloody Sunday" March. Transcript of speech available at http://time.com/3736357/barack-obama-selma-speech-transcript/. Notably, this address is replete with what I would take to be religious language, much of which would not seem to fulfill Rawls' proviso.
} 
At this point there are myriad prescriptions I could offer to bring what I take to be an Arendtian vision of politics more clearly into view. While this has not been the primary goal of my project (nor was it hers) I outline just a few now, some of which I think she would endorse as positive contributions to our discourse. Firstly, what is needed in our public deliberation is the acceptance of what Stout termed "immanent criticism"- - which is to say, respectful and honest engagement with discrete interlocutors while continuing to persuade them from one's own point of view - in response to particular laws and policies. As Stout asserts, citizens must feel able to voice their sincere opinions to their compatriots, which includes not just acknowledging reasoning that is rooted in specialized vantage points, but recognizing the specific claim a citizen makes with her speech and action. Such a political discourse is more conversational and ultimately more truthful, allowing our reasons to proliferate in the public sphere and influence our fellow citizens without manipulation. Approving this kind of dialogue is itself an acceptance of particularity; not just of arguments, but of citizens and their perspectives, resembling a more Arendtian view of public life.

Secondly, we ought to model our political engagement on those who came before us: that is, we ought to follow the examples of those whose involvement with human affairs we find inspiring. Throughout this thesis, I have named several such exemplars. Of course, Arendt has been a key figure for my understanding of politics, but I have also referred to others-namely, King, Lincoln, and some of Charlottesville's local leaders-who I feel embody the democratic spirit. This is not to say our chosen paragons need be homogenous; while I think Havel, Wałęsa, and Gokhale provide an unparalleled perspective on political engagement and how to reinvigorate the life of a community, as an Arendtian I would encourage others to propound their 
own archetypal citizens. Such an activity cultivates a politically engaged atmosphere in and of itself, and while modelling our engagement on theirs will not pave our path, it will provide us with an example to follow, a still blemished but more agreeable muse.

Finally, on my view we ought to regard our political interactions (at least in their infantile stages) as "awkward friendships." ${ }^{260}$ Like any new friendship, politics can be cumbersome. Indeed, the postulating and interjecting that is concomitant with political engagement often fails to make for good public relations, which is why systems like the town council thrive on the fact that Citizen A has lived two doors down from Citizen B for the last quarter-century. Unfortunately, most organizations do not have the luxury of geographical intimacy. And yet, even at the outset we invest in our friendships not solely to protect ourselves from harm, but because we can recognize their intrinsic value, as well as their potential to help us lead flourishing lives. Harnessing this potential and translating these delicate relationships into steadfast ones will doubtlessly demand tremendous amounts of effort (and perhaps a bit of good fortune), not to mention the unrelenting patience it takes to foster rapport in our associations with one another. In the end, however, these friendships may be the most treasured entity we have, a necessary component of our human condition. Although many more details could be uncovered in a project such as this, I must now end it, sending it into the world and following Arendt's example in "learn[ing] from what other people do with it."261

\footnotetext{
${ }^{260}$ I attribute the notion of awkward friendships in politics to legal scholar John Inazu, given in a public lecture on January 29, 2015. For additional perspectives on politics and friendship, see Guido de Graaff, Politics in Friendship: $A$ Theological Account (London: Bloomsbury, 2014), as well as Danielle Allen's Talking to Strangers.

${ }^{261}$ Quoted in The Human Condition, xx.
} 


\section{Works Cited}

Ackerman, David M. "The Religious Freedom Restoration Act: Its Rise, Fall, and Current Status." Congressional Research Report for Congress. April 17, 1992. http://www.justice .gov/sites/default/files/jmd/legacy/2014/05/30/crsrept-1992.pdf.

Allen, Amy. "Power, Subjectivity, and Agency: Between Arendt and Foucault." International Journal of Philosophical Studies 10, no. 2 (2010): 131-149.

Allen, Danielle. Talking to Strangers: anxieties of citizenship since Brown v. Board of Education. Chicago: University of Chicago, 2004.

Arendt, Hannah. Between Past and Future: Eight Exercises in Political Thought. New York: Penguin Books, 2006.

—. Crises of the Republic. New York: Harcourt Brace Jovanovich, 1972.

—. Eichmann in Jerusalem: A Report on the Banality of Evil. New York: Penguin Books, 1963.

—. The Human Condition. Chicago: The University of Chicago, 1958.

—. Lectures on Kant's Political Philosophy, edited by Ronald Beiner. Chicago: The University of Chicago, 1992.

—. On Revolution. New York: Penguin Books, 1963.

—. The Origins of Totalitarianism. San Diego, CA: Harvest Books, 1951.

—. The Promise of Politics. New York: Schocken Books, 2005.

Aron, Raymond. Democracy and Totalitarianism: A Theory of Political Systems. Ann Arbor, MI: University of Michigan, 1990.

Asad, Talal. Formations of the Secular: Christianity, Islam, Modernity. Stanford, CA: Stanford University, 2003.

-. Genealogies of Religion: Discipline and Reasons of Power in Christianity and Islam. Baltimore, MD: Johns Hopkins University, 1993.

—. On Suicide Bombing. New York: Columbia University, 2007.

Audi, Robert and Robert Wolterstorff. Religion in the Public Square: The Place of Religious Convictions in Political Debate. London: Rowman \& Littlefield, 1997.

Baehr, Peter. The Portable Hannah Arendt. New York: Penguin, 2000. 
Baxter, Hugh. Habermas: The Discourse Theory of Law and Democracy. Stanford, CA: Stanford University, 2011.

Benhabib, Seyla. The Reluctant Modernism of Hannah Arendt. Thousand Oaks, CA: SAGE Publications, 1996.

-. Situating the Self: Gender, Community, and Postmodernism in Contemporary Ethics. New York: Routledge, 1992.

Bernauer, James W., editor. Amor Mundi: Explorations in the Faith and Thought of Hannah Arendt. Boston: Martinus Nijhoff, 1987.

Bradshaw, Leah. Acting and Thinking: The Political Thought of Hannah Arendt. Toronto: University of Toronto, 1989.

Bretherton, Luke. Resurrecting Democracy: Faith, Citizenship, and the Political of a Common Life. Cambridge, UK: Cambridge University, 2015.

Butler, Judith. Excitable Speech: A Politics of the Performative. New York: Routledge Publishing, 1997.

—. Gender Trouble: Feminism and the Subversion of Identity. New York: Routledge Publishing, 1990.

—. Giving an Account of Oneself. New York: Fordham University, 2005.

—. Precarious Life: The Powers of Mourning and Violence. New York: Verso, 2004.

—. The Psychic Life of Power: Theories in Subjection. Stanford, CA: Stanford University, 1997.

—. Undoing Gender. New York: Routledge Publishing, 2004.

Butler et. al. The Power of Religion in the Public Sphere. New York: Columbia University, 2011.

Calhoun, Craig and Eduardo Mendieta, Jonathan VanAntwerpen, editors. Habermas and Religion. Malden, MA: Polity Press, 2013.

Calhoun, Craig and John McGowan, editors. Hannah Arendt and the Meaning of Politics. Minneapolis, MN: University of Minnesota, 1997.

Canovan, Margaret. Hannah Arendt: A Reinterpretation of Her Political Thought. Cambridge, UK: Cambridge University, 1992.

—. The Political Thought of Hannah Arendt. London: J.M. Dent and Sons, 1974. 
Cillizza, Chris. "The Koch Brothers have funded 44,000 ads in the 2014 election." The Washington Post (Washington, D.C.), September 4, 2014.

Collins et. al. Economic Apartheid in America: A Primer on Economic Inequality and Insecurity. New York: New Press, 2005.

Connolly, William E. The Augustinian Imperative: A Reflection on the Politics of Morality. Oxford: Rowman and Littlefield, 1993.

—. Why I Am Not a Secularist. Minneapolis, MN: University of Minnesota, 1999.

de Graffe, Guido. Politics in Friendship: A Theological Account. London, UK: Bloomsbury Publishing, 2014.

Diamantides, Marinos and Adam Gearey, editors. Islam, Law, and Identity. Oxford: Routledge-Cavendish, 2011.

Drucker, Peter F. “Really Reinventing Government.” The Atlantic Monthly, February 1995.

Eberle, Christopher J. Religious Conviction in Liberal Politics. Cambridge, UK: Cambridge University, 2002.

Foucault, Michel. The Archaeology of Knowledge. New York: Pantheon Books, 1972.

—. Discipline and Punish: The Birth of the Prison. New York: Vintage Books, 1979.

-. The History of Sexuality, Volume 1: An Introduction, trans. Robert Hurley. New York: Vintage, 1990.

-. Power/Knowledge: Selected Interviews and Other Writings 1972-1977, edited by Colin Gordon. New York: Pantheon Books, 1980.

Fraser, Nancy. Unruly Practices:Power, Discourse, and Gender in Contemporary Social Theory. Minneapolis: University of Minnesota, 1989.

Fultner, Barbara, editor. Jürgen Habermas: Key Concepts. Durham, UK: Acumen Publishing, 2011.

Greenawalt, Kent. Does God Belong in Public Schools? Princeton, NJ: Princeton University, 2005.

Gilens, Martin and Benjamin I. Page. "Testing Theories of American Politics: Elites, Interest Groups, and Average Citizens." Perspectives on Politics 12, no. 3 (September 2014): 564-581. 
Habermas, Jürgen. Between Facts and Norms: Contributions to a Discourse Theory of Law and Democracy. Cambridge, UK: Polity Press, 1996.

-. Between Naturalism and Religion: Philosophical Essays. Cambridge, UK: Polity Press, 2008.

—. "Hannah Arendt's Communications Concept of Power." Social Research 43, no. 4 (1977): 3-24.

-. Religion and Rationality: Essays on Reason, God, and Modernity. Cambridge, UK: Polity Press, 2002.

—. Truth and Justification. Cambridge, MA: Polity Press, 2003.

Hardt, Michael and Antonio Negri. Commonwealth. Cambridge, MA: Belknap Press, 2009.

Hargreaves, John. Sports, Power and Culture: A Social and Historical Analysis of Popular Sports in Britain. New York: St. Martin's Press, 1986.

Harris, Sam. The End of Faith: Religion, Terror, and the Future of Reason. New York: Norton , 2005.

Havel, Vaclav. The Art of the Impossible: Politics as Morality in Practice. New York: Knopf, 1994.

Hay, Colin. Why We Hate Politics. Cambridge, UK: Polity, 2007.

Hill, Melvyn A., editor. Hannah Arendt: The Recovery of the Public World. New York: St. Martin's Press, 1979.

Hofstadter, Douglas. Gödel, Escher, Bach: an Eternal Golden Braid. New York: Basic Books, 1979.

Honig, Bonnie, editor. Feminist Interpretations of Hannah Arendt. University Park, PA: Penn State University, 1995.

Howard, Philip K. The Rule of Nobody: Saving America From Dead Laws and Broken Government. New York: W.W. Norton and Company, 2014.

Isaac, Jeffrey. Arendt, Camus, and Modern Rebellion. Ithaca: Cornell University, 1998.

Lefort, Claude. The Political Forms of Modern Society: Bureaucracy, Democracy, Totalitarianism. Cambridge, UK: Polity Press, 1986. 
Lessig, Lawrence. Republic, Lost: How Money Corrupts Congress — and a Plan to Stop It. New York: Hachette Book Group, 2011

Mahmood, Saba. Politics in Piety: The Islamic Revival and the Feminist Subject. Princeton, NJ: Princeton University, 2005.

March, Andrew. "Speaking about Muhammed, Speaking for Muslims." Critical Inquiry 37, no. 4 (2011): 806-821.

McNay, Lois. "Subject, Psyche, and Agency: The Work of Judith Butler." Theory, Culture and Society 16, no. 2 (1999): 175-193.

Mouffe, Chantal. The Democratic Paradox. New York: Verso, 2000.

Obama, Barack. "Address on the 50th Anniversary of the Selma, Alabama March." Delivered at the Edmund Pettus Bridge, Selma, Alabama, March 7, 2015.

Passerin d'Entrèves, Maurizio. The Political Philosophy of Hannah Arendt. New York: Routledge, 1994.

Pew Research Center. “Public Sees Religion's Influence Waning." Pew Research Center: Religion and Public Life. http://www.pewforum.org/2014/09/22/public-sees-religionsinfluence-waning- $2 /$.

Pitkin, Hanna Fenichel. The Attack of the Blob: Hannah Arendt's Concept of the Social. Chicago: The University of Chicago, 1998.

-. Wittgenstein and Justice: On the Significance of Ludwig Wittgenstein for Social and Political Thought. Berkeley, CA: University of California, 1972.

Rainbow, Paul, editor. Ethics: Subjectivity and Truth. New York: The New Press, 1994.

—. The Foucault Reader. New York: Pantheon, 1984.

Rawls, John. "The Idea of Public Reason Revisited", The University of Chicago Law Review 64: no. 31997.

—. Political Liberalism. New York: Columbia University, 2005.

Shapiro, Ian. The State of Democratic Theory. Princeton, NJ: Princeton University, 2003.

Stout, Jeffrey. Blessed Are the Organized: Grassroots Democracy in America. Princeton, NJ: Princeton University, 2010.

—. Democracy and Tradition. Princeton, NJ: Princeton University, 2004. 
-. Ethics After Babel: The Language of Morals and Their Discontents. Boston: Beacon Press, 1988.

Sunstein, Cass. Wiser: Getting Beyond Groupthink to Make Groups Smarter. Cambridge, MA: Harvard Business Review Press, 2015.

Taylor, Charles. "Foucault on Freedom and Truth.” Political Theory 12, no. 2 (1984): 152-183.

Van der Walt, Johan. "Law and the Space of Appearance in Arendt's Thought." In Hannah Arendt and the Law, edited by Marco Goldoni and Christopher McCorkindale, 63-88. Oxford, UK: Hart Publishing, 2012.

Villa, Dana, editor. The Cambridge Companion to Hannah Arendt. Cambridge, UK: Cambridge University, 2000.

—. Public Freedom. Princeton, NJ: Princeton University, 2008.

White, Stephen K., editor. The Cambridge Companion to Jürgen Habermas. Cambridge, UK: Cambridge University, 1995.

Young-Bruehl, Elisabeth. Hannah Arendt: For Love of the World. New Haven, CT: Yale University, 1982.

—. Why Arendt Matters. New Haven, CT: Yale University, 2006. 